BANCA D'ITALIA

E U ROS I S T E M A

Temi di discussione

(Working Papers)

The catalytic role of IMF programs

by Claudia Maurini and Alessandro Schiavone 



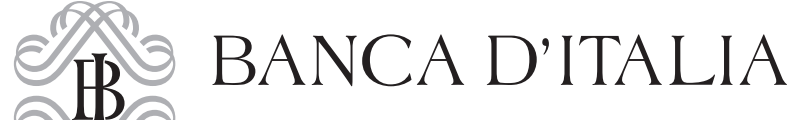

E UROS I S T E MA

\section{Temi di discussione}

(Working Papers)

The catalytic role of IMF programs

by Claudia Maurini and Alessandro Schiavone

Number 1331 - April 2021 
The papers published in the Temi di discussione series describe preliminary results and are made available to the public to encourage discussion and elicit comments.

The views expressed in the articles are those of the authors and do not involve the responsibility of the Bank.

Editorial Board: Federico Cingano, Marianna Riggi, Monica Andini, Audinga Baltrunaite, Marco Bottone, Davide Delle Monache, Sara Formai, Francesco Franceschi, Adriana Grasso, Salvatore lo Bello, Juho Taneli Makinen, Luca Metelli, Marco Savegnago.

Editorial Assistants: Alessandra Giammarco, Roberto Marano.

ISSN 1594-7939 (print)

ISSN 2281-3950 (online)

Printed by the Printing and Publishing Division of the Bank of Italy 


\title{
THE CATALYTIC ROLE OF IMF PROGRAMS
}

\author{
by Claudia Maurini* and Alessandro Schiavone*
}

\begin{abstract}
This paper investigates the impact of IMF programs on private capital flows in the assisted countries. We look at the impact on inflows and outflows of both traditional and precautionary programs, also taking into account the characteristics of the programs. Using the entropy balancing method to address the selection bias, we find that traditional IMF programs have an anticatalytic effect on private capital inflows; this effect is mainly driven by programs that went off-track and by exceptional access programs. By contrast, precautionary programs are found to have a catalytic effect, working mainly through outflows.
\end{abstract}

JEL Classification: F33, F34, G11, G15.

Keywords: International Monetary Fund, catalysis, capital flows.

DOI: $10.32057 / 0$. TD.2021.1331

\section{Contents}

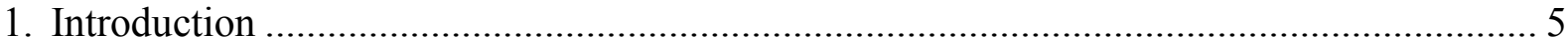

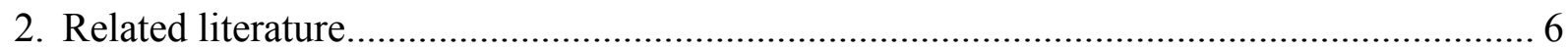

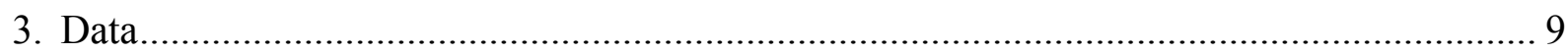

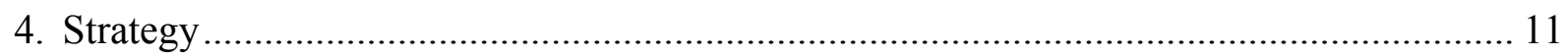

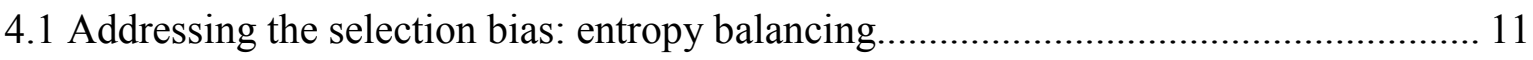

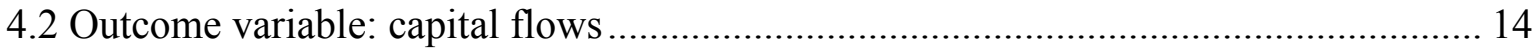

4.3 Treatment variable: IMF programss ....................................................................... 14

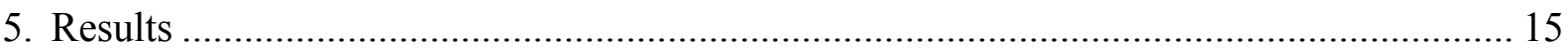

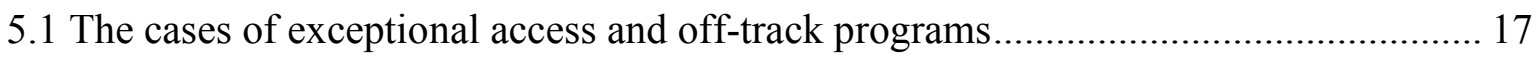

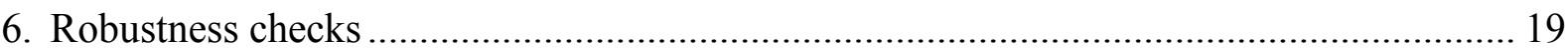

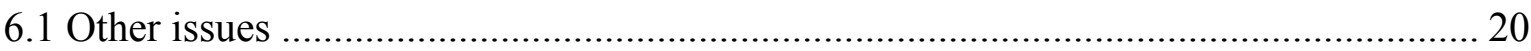

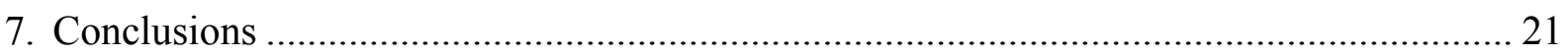

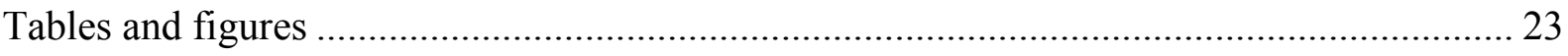

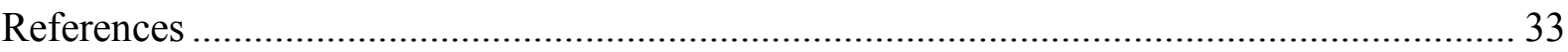
${ }^{*}$ Bank of Italy, Directorate General for Economics, Statistics and Research, International
Relations and Economics Directorate. 



\section{Introduction $^{1}$}

According to the IMF Articles of Agreement, the aim of the financial assistance provided by the IMF is to help countries undergoing a balance of payments crisis restore external equilibrium without having to resort to measures entailing a disproportionate cost for the economy. ${ }^{2}$ Even though, at a first glance, this definition may appear straightforward, from an empirical perspective assessing the success of IMF programs is challenging. First, there is no consensus in the literature about the transmission channels and the various factors affecting the effectiveness of IMF programs. Second, the empirical strategy adopted to investigate the effectiveness of IMF programs needs to address the selection bias stemming from the fact that countries asking for IMF's assistance are faced with actual or potential balance of payments problems, and hence are different from countries that do not request such assistance.

In this paper, we focus on the catalytic effect of IMF programs, investigating whether the intervention of the Fund increases the propensity of private investors to lend to program countries. Note that private financing represents a crucial ingredient for the success of IMF programs, since the task of the IMF is not to finance the external deficit of borrowing countries, but to provide a breathing space to national authorities, allowing them to implement reforms aimed at restoring external viability. In some theoretical works (Corsetti et al. (2003)) the success of IMF programs depends on the strategic interaction between the country and private investors. The country will restore external equilibrium only if it implements the package of reforms agreed with the Fund; on the other hand, private investors will finance countries assisted by the Fund only if they believe that the program will work out. The coordination role of the Fund is crucial since it enables the alignment of the incentives of borrowing countries to investors' expectations: in fact, on the one hand, the IMF's financial assistance alleviates the burden of the economic adjustment; on the other hand, by approving programs, the IMF provides its seal of approval on the policy measures that the country's policy-makers commit to in order to push through the economic reforms needed to restore external viability.

Previous studies find no systematic evidence on the catalytic effect; aside from methodological aspects, there seems to be heterogeneity across countries, as private investors tend to discriminate among program countries according to their economic fundamentals (Mody \& Saravia (2003)). Some papers (see Erce \& Riera-Crichton (2015)) point also to asymmetric effects depending on the type and the direction of investment flows. Other factors that need to be taken into account concern the size of the financial assistance (Krahnke

\footnotetext{
${ }^{1}$ The views expressed in the paper are those of the authors and do not necessarily reflect those of the Bank of Italy.

${ }^{2}$ Article $1(\mathrm{~V})$ of the Articles of Agreement states that one of the purposes of the IMF is "to give confidence to members by making the general resources of the Fund temporarily available to them under adequate safeguards, thus providing them with the opportunity to correct maladjustments in their BoP without resorting to measures destructive of national or international prosperity".
} 
(2020)), and the degree of compliance with program conditionality (Kutan et al. (2012)). Our paper aims to contribute to the empirical literature, using a relatively new methodology (entropy balancing) that allows us to deal with selection bias, without having to make strong assumptions on the counterfactual; moreover, we analyze the catalytic effect, having care to distinguish between IMF traditional and precautionary programs, ${ }^{3}$ and to account for the size of IMF loans, and the degree of compliance with IMF conditionality.

Our analysis covers Stand-by Arrangements and precautionary programs approved after 2002. The sample includes 44 countries and 84 arrangements; we use quarterly data for a larger number of economies since we compare program countries with a synthetic counterfactual obtained from other countries having similar characteristics in terms of macroeconomic variables. In our model we also take into account capital account openness as program countries often resort to capital flows management measures to prevent disruptive outflows.

The main results of this study are: i) Stand-by Arrangements are associated with an anticatalytic effect on inflows whereas precautionary programs show a catalytic effect on outflows; ii) exceptional access programs (a subset of the Stand-by Arrangements) are associated with a strong anticatalytic effect; with regard to Stand-by Arrangements within normal access limits, the adverse impact of IMF programs is much smaller on gross inflows and not significant on net inflows; iii) the anticatalytic effect is accentuated for Stand-by Arrangements featuring a low level of compliance with IMF conditionality (i.e. programs that go off-track). To sum up, we find evidence of a catalytic effect for precautionary programs; by contrast, the ability of the Fund to stimulate private financial flows towards countries proves significantly hampered in the case of exceptional access programs and when countries fail to comply with IMF conditionality.

\section{Related literature}

The objective of IMF programs is to contribute to restore external viability of countries facing balance of payments crises, by providing support in such a way that recipient countries are not forced to adopt measures detrimental for national prosperity. The implication is that for IMF intervention to be effective, it is paramount that private investors resume lending to program countries; therefore the analysis of the catalytic effects is crucial to assess the success of IMF lending. Some theoretical works (e.g. Corsetti et al. (2003)) emphasize the coordination role of the Fund which permits to align the incentives of borrowing countries with investors' expectations: in fact, on the one hand, the IMF's financial support alleviates the burden of the economic adjustment; on the other hand, the IMF re-

\footnotetext{
${ }^{3}$ Here and in the rest of the paper, we define traditional programs as ones aimed at resolving actual balance of payments needs, where the country draws on the resources made available by the Fund.
} 
assures investors that countries under program will push through the actions and reforms needed to restore external viability. According to Cottarelli \& Giannini (2002), there are two main channels through which catalysis materializes: the "seal of approval effect" and the liquidity mechanism. The first channel is linked to the conditionality embedded in IMF programs, which reassures foreign investors that appropriate policies will be implemented to solve balance of payments problems (Tirole (2002)); the second channel has been explored by Zettelmeyer (2000) which demonstrates that under certain conditions, IMF programs reduce the probability of self-fulfilling run purely caused by illiquidity problems, even in the absence of explicit conditionality.

In practice, several factors may hamper the catalytic function of the financial assistance provided by the IMF. First, given the IMF preferred creditor status, foreign investors may be reluctant to lend to countries under program since they fear that, in case of restructuring, they will be penalized (Mody \& Saravia (2003)). Second, moral hazard may be source of concern for investors (Dreher (2006)), since borrowing countries, expecting to be bailed-out by the IMF, may have weak incentives to implement unpopular but necessary policies to solve the crisis.

From an empirical standpoint, assessing the effectiveness of IMF programs is challenging. First, the multiplicity of channels complicates the identification strategy; second, as borrowing countries' generally are in bad economic conditions, any analysis made without properly addressing the selection bias, leads to underestimate the catalytic effects. Not surprisingly, the results of the empirical literature investigating the catalytic effects of IMF programs are mixed. For example Bird \& Rowlands (2002) run panel regression for a sample of emerging economies and find that catalytic effects are weak and idiosyncratic. Mody \& Saravia (2003), examine whether IMF programs help recipient countries to tap international bond markets; by using a two-equation model on individual issuances, they find that financial conditions depend on country economic fundamentals, and that catalytic effects materialize only for countries, whose external debt is not too high relative to FX reserves. Along the same lines, van der Veer \& de Jong (2013), use IV approach to test if IMF programs stimulate private capital flows in middle-income countries, and find evidence of catalytic effects only for solvent countries.

Other aspects to take into account pertain to program design, namely the type of facility, the scope of conditionality and the size of financial support. For example, according to Mody \& Saravia (2003) catalytic effects are stronger for those programs which "turned" precautionary, that are those under which countries decided not to draw any amount; this finding suggests that the liquidity channel might not be the main mechanism at play and points to the opportunity of distinguishing between standard and precautionary programs. Diaz-Cassou et al. (2006) use propensity score matching technique to test the impact of traditional IMF programs, such as SBA and EFF; they find that these programs are asso- 
ciated with catalytic effects only when they are used as precautionary facilities.

Chapman et al. (2015) adopt IV approach to disentangle the various channels through which IMF programs affect borrowing countries' financial conditions, taking into account both IMF conditionality and the liquidity mechanism. They find that programs countries benefit of lower interest rates the lower the size of the loans; the scope of conditionality turns out to be also relevant, as lower interest rates are associated with a higher number of conditions; the authors argue that program reforms reduce the financing needs that must be filled by the private sector, compressing the probability of a liquidity crisis. The compliance with IMF conditionality also matters; Edwards (2005) suggests that failure to implement agreed reforms has negative repercussions on capital markets' access; Kutan et al. (2012) use event study methodology to assess the effects on asset prices of news regarding the implementation of the IMF program for Indonesia during the Asian crisis; they found that frictions between the IMF and local authorities are associated with negative effects on the financial sector.

With regard to the size of IMF financial assistance, Benelli (2003) by comparing actual private net capital inflows to projections contained in IMF programs, finds that effective inflows are negatively correlated with the size of IMF loans and that exceptional access programs are associated with anticatalytic effects; in fact, for these programs IMF projections on capital inflows tend to be too optimistic, so that the financing gap looks lower than it should be. Krahnke (2020) uses IV approach and finds evidence of catalytic effects of IMF programs; however these effects reverse when the size of financial assistance exceed certain thresholds.

Catalytic effects depend also on the funding structure of borrowing countries. For example, Erce \& Riera-Crichton (2015) use IV approach to look into the effects of IMF programs on both gross and net flows, distinguishing between flow types, and taking into account investors' nationality. They find no effects in net flows, but this finding derives from the combination of opposite effects on gross inflows and gross outflows; indeed, foreigners tend to cut their investments in the program countries, whereas residents repatriate funds, mainly by decreasing banking outflows; it suggests that IMF programs are successful in preventing capital flights by domestic investors, whereas they are not effective in attracting capital flows from abroad. These findings highlights the importance of looking into gross flows and distinguishing between flow types.

Our paper contributes to the existing literature on the catalytic effects on several fronts: first, in order to address selection bias, we use a relatively new approach (the entropy balancing) that to our knowledge has not yet been employed to assess the catalytic effects of IMF programs. Second, following Diaz-Cassou et al. (2006), we distinguish between drawing and precautionary programs; however, while they focus on traditional programs, such as SBA and EFF, our dataset includes also precautionary facilities introduced after the global financial crisis, such as the Flexible Credit Line (FCL) and the Precautionary 
Liquidity Line (PCL). Third, our analysis deals with some features of IMF programs, like the size of financial support, and the compliance with IMF conditionality, which may affect the propension of investors to lend to borrowing countries, and whose effects on capital flows are still to be fully investigated. Finally, in order to account for the heterogeneity across investors, related to their nationality and asset holdings, we analyze the effects of IMF programs on both gross and net flows, distinguishing between the main types of investment.

\section{Data}

We conduct an econometric analysis on the impact of IMF programs on capital flows, taking also into account the economic determinants of such flows. Data on IMF programs (facility type, time length, loan size, number of reviews accomplished) are taken from the MONA database. ${ }^{4}$ Our variable of interest is a dummy which takes value 1 if the country is under an IMF program in a given quarter. We call this variable "IMF traditional" when considering non-precautionary SBA and "IMF precautionary" when considering FCL, PLL and precautionary SBA. Our study covers IMF programs approved between 2002 and $2018,{ }^{5}$ which include Stand-By Arrangements (67) and precautionary facilities (17), such as the Flexible Credit Line (FCL) and the Precautionary Liquidity Line (PCL). Our sample covers 44 borrowing countries (all emerging economies except Greece and Iceland), ${ }^{6}$ while the whole dataset also includes other 68 countries which are used within the algorithm to build the synthetic control. ${ }^{7}$

Note that while Stand-By Arrangements aim to resolve actual BoP crises, the objective of precautionary programs is to reassure investors that in case of a crisis the country can count on additional resources made available by the IMF to deal with it. Our sample includes 28 precautionary SBA, i.e. programs that the countries' authorities decide to treat as precautionary, without drawing resources from the available amounts. In our analysis, in contrast with most of the existing literature, we distinguish precautionary SBA from

\footnotetext{
${ }^{4}$ The Monitoring of Fund Arrangements (MONA) database covers the economic objectives and outcomes of Fund-supported programs since 2002. It provides a cumulative history of Fund-supported programs from Executive Board approval through its completion.

${ }^{5}$ We provide in the annex the list of programs included in our sample. We exclude programs approved before 2002 because the current guidelines on conditionality adopted in that year characterize IMF program design (IRC (2019)). In addition, in the MONA database there is a discontinuity in the reporting of IMF programs depending on they were approved before/after 2002.

${ }^{6}$ Other advanced economies like Ireland, Cyprus and Portugal, which accessed IMF funds through the Extended Fund Facilities (EFF), are not considered in the main analysis, which covers only Stand-by arrangements (SBA) and precautionary programs.

${ }^{7}$ Algeria, Australia, Austria, Bahrain, Bangladesh, Belgium, Brunei Darussalam, Burkina Faso, Canada, Chile, China, Côte d'Ivoire, Cyprus, Czech Republic, Denmark, Egypt, Ethiopia, Finland, France, Germany, Ghana, Hong Kong SAR, India, Indonesia, Ireland, Iran, Israel, Italy, Japan, Kazakhstan, Kenya, Korea, Kuwait, Lebanon, Malaysia, Malta, Moldova, Morocco, Myanmar, Netherlands, New Zealand, Nicaragua, Nigeria, Norway, Oman, Panama, Philippines, Poland, Portugal, Romania, Russia, Saudi Arabia, Singapore, Slovenia, South Africa, Spain, Sweden, Switzerland, Tanzania, Thailand, Togo, Uganda, United Kingdom, United States, Venezuela, Vietnam, Yemen, Zambia.
} 
traditional ones and pool them with precautionary facilities tout court. In fact, SBA can also be used as a precautionary arrangements for countries that do not meet the strong prequalification conditions required to access precautionary facilities, such as the FCL and PLL. Moreover precautionary SBA feature a lower number of conditions than standard ones and rely to a larger extent on quantitative indicators and indicative targets rather than structural benchmarks (see IRC (2019)). In addition, they have better compliance rates.

Another aspect we take into account is whether countries in fact comply with program conditionality; to this aim, we generate a dummy (off-track) which takes value 1 if the number of completed reviews is less than $50 \%$ of those scheduled; indeed, for programs with a ratio below this threshold, we deduce that authorities did not meet most of the conditions attached to the program. We also take into account the size of loans, distinguishing among SBA arrangements those exceeding normal access limits (21 programs). ${ }^{8}$ On average, the size of loans is 4.8 per cent of GDP for the whole sample; it is significantly higher for programs exceeding normal access limits (on average 6.2 against 4.3 per cent).

Our dependent variables are cross-border financial flows taken from IMF Balance of Payment statistics with quarterly frequency from 2002 to 2018. Like most of the other variables in our dataset, we scale flows to GDP. Inflows (outflows) are defined as changes in liabilities (assets) of residents towards foreigners. Consistently with most studies of this kind, we exclude derivatives, since the underlying data are too volatile and erratic. As we are interested in studying the impact of IMF intervention for different types of financial flows, along with country aggregate flows we use data on foreign direct, portfolio and other investments, which include cross-border banking flows. We focus on private investors, by excluding official flows recorded in BoP statistics, represented by loans received (as well as portfolio investments made) by the Central bank and the General Government. We study the impact of IMF programs on both gross and net flows, since in our view both measures are relevant; indeed, analyzing gross flows allows assessing if IMF interventions affect investment decisions, while the impact of net flows reflects the contribution of IMF program to external adjustment. From this perspective, it is important to consider that IMF programs typically aim at improving the current account balance, lowering external financial needs; in this regard, Benelli (2003) points out that a reduction of net inflows should not lead to the conclusion that IMF programs failed to generate catalytic effects.

As noted above, the confounding covariates used for the entropy balancing (and subsequently included in the weighted regressions) are chosen according to their ability to affect both the dynamic of capital flows and the countries' participation in IMF programs. As

\footnotetext{
${ }^{8}$ These limits are normally expressed as a ratio to country quotas and set on an annual and cumulated basis. Both limits have changed during the period of the analysis: from $100 \%$ of quota on an annual basis and $300 \%$ overall before 2009, to $200 \%$ annual and $600 \%$ overall from 2009 to 2016, and following the IMF quota increase in 2016 , to $145 \%$ and $435 \%$, respectively.
} 
commonly done in the literature on the determinants of capital flows, we consider both country specific and global variables (also known as push and pull factors). ${ }^{9}$ In particular, our list of covariates includes (i) economic growth (quarterly GDP growth), (ii) trade openness (given by the sum of imports plus exports scaled on the GDP), (iii) the current account balance (as percent of GDP), (iv) inflation, (v) foreign exchange reserves (as percent of GDP), (vi) an index of capital $\operatorname{controls}^{10}$, (vii) a synthetic index of political risk taken from ICRG (International Country Risk Guide), ${ }^{11}$ (viii) VIX, (ix) the Fed funds interest rate.

Table 2 reports the summary statistics for the dependent variables and covariates. All data are windsorized at the $5^{\text {th }}$ and $95^{\text {th }}$ percentiles and covariates are lagged one period to address the issue of reverse causality. Table 1 reports variable definitions and sources. Table 3 shows the correlation among the covariates, the capital flows variables (gross inflows, gross outflows and net inflows) and the IMF dummy, distinguishing between traditional and precautionary programs. The coefficients show that almost all the covariates correlate with inflows and outflows; while most variables are linked to the traditional IMF program dummy ("IMF traditional"), the dummy for the precautionary programs is correlated with fewer covariates, such as the Political Risk Rating, trade openness and the global variables (VIX and US interest rate).

\section{Strategy}

\subsection{Addressing the selection bias: Entropy balancing}

The issue of selection bias in this kind of studies stems from the fact that countries that receive financial assistance from the IMF do so in response to an actual or potential balance of payments crisis and this makes them different from countries that do not receive assistance. Therefore the simple evaluation of the difference in capital inflows and outflows between supported and not supported countries would capture not just the impact of the IMF program, but also the intrinsic pre-program differences among country groups.

As discussed in section 2, the issue of selection bias has been addressed in various ways in the literature, but mainly through instrumental variables or through techniques borrowed from the literature evaluating the impact of public policies. In this paper, we use a relatively new approach developed by Hainmueller (2012) and Hainmueller \& Xu (2013), namely the entropy balancing method. This method has been used recently by Balima \& Sy (2019) to assess the impact of IMF programs on the probability of sovereign defaults,

\footnotetext{
${ }^{9}$ See, for example, Broner et al. (2013), Erce \& Riera-Crichton (2015) and Koepke (2019) for a survey of the empirical literature on push and pull factors.

${ }^{10}$ The $k a$ index is taken from Fernandez et al. (2016) and is a de jure measure of financial integration, which takes value 1 if capital controls are applied to all financial transaction types.

${ }^{11}$ It is a composite index which takes into account multiple aspect of the political situation of the country. More information can be found on www.prsgroup.com/explore-our-products/international-country-riskguide/.
} 
by Balima (2017) to analyze the effect of domestic sovereign bond market participation on financial dollarization and by Neuenkirch \& Neumeier (2016) to study the effect of U.S. sanctions on poverty.

The entropy balancing method is a data pre-processing scheme for observational studies with binary treatment, whose objective is to create a comparable counterfactual against which it is possible to evaluate the performance of the group of the treated; it is a generalization of conventional matching methods and can be seen as a bridge between the synthetic control method and the propensity score weighting one, since it envisages the following two steps:

- Create a weighting scheme (i.e. assign a scalar weight to each sample unit) which allows to satisfy pre-specified constraints regarding the sample moments of the distributions of the covariates $X$ for the treated and the non-treated observations (this mimics the creation of a synthetic control group);

- Use the weights from the first step in a weighted regression analysis where the outcome of interest is the dependent variable and the treatment indicator is the main explanatory variable (this step mimics the weighting procedure performed by the propensity score weighting).

With respect to the propensity score matching or weighting, this method has the advantage of avoiding the need to check for covariates balance between the control and treated groups, since the balance is the very condition under which the counterfactual is built; in addition, it does not require the specification of a model for treatment assignment (in our case a model for participation in IMF programs), which can raise concerns over potential misspecification, multicollinearity, or wrong choice of the functional form. Finally, the second step of the entropy balancing procedure allows to consider the panel dimension of the data and the role of additional dummies that may interact with the treatment one. ${ }^{12}$ The latter feature is especially important for our analysis, since our data have a strong panel dimension (with many countries and quarterly observations) and we want to characterize additional aspects of IMF programs, beyond their mere presence/absence in a given country and a given quarter.

In our analysis, we use the entropy balancing methodology in order to compare the capital flows to (from) countries that have an IMF program to those of countries without a program that are as similar as possible to the former. The average difference in capital flows between program countries and the synthetic control group must then be due to treatment, that is, the presence of an IMF program. In this sense, the empirical approach mimics a randomized experiment by balancing the treatment and the control group based on observable characteristics.

The entropy balancing approach is hence based on the idea that the adoption of an IMF

\footnotetext{
${ }^{12}$ Hainmueller (2012) in a Montecarlo simulation finds that entropy balancing outperforms propensity score matching in terms of estimation bias and mean square error.
} 
program represents the treatment and the private capital inflows/outflows represent the outcome variables. The units of observation are country-quarter data; observations with (without) a program represent the treatment (control) group. Our variable of interest here is the Average Treatment Effect on the Treated (ATT), which can be expressed as:

$$
A T T=E\left(Y_{1} \mid D=1\right)-E\left(Y_{0} \mid D=1\right)
$$

where $Y$ is the outcome variable measuring the relevant aspect of capital flows, $D$ indicates if the unit of observation is subject to the treatment $(D=1)$ or not $(D=0)$. Consequently, $E\left(Y_{1} \mid D=1\right)$ denotes the capital flows for program countries during the program period and $E\left(Y_{0} \mid D=1\right)$ represents the counterfactual outcome for the same countries if they had not adopted programs. Given that we cannot observe the last one, and that the treatment is not randomly assigned to the units, the entropy balancing method helps us compare program and non-program units that are as close as possible with respect to some observables characteristics that meet these two conditions: (i) they are correlated with a country decision to sign a program with the Fund and (ii) they are associated with the dynamic of capital flows. Afterwards, the above equation can then be rewritten as follows:

$$
A T T=E\left(Y_{1} \mid D=1, X=x\right)-E\left(Y_{0} \mid D=0, X=x\right)
$$

where $X$ is a vector of observables confounding covariates that may affect both the decision to sign a program and the capital inflows/outflows to the country. In this case $E\left(Y_{1} \mid D=1, X=x\right)$ is the expected value of capital flows for program units and $E\left(Y_{0} \mid D=\right.$ $0, X=x)$ is the expected value of capital flows for the synthetic control units.

Following Neuenkirch \& Neumeier (2016), we choose the balance constraints that impose equal covariate means and variances across program and non-program observations. In the second step, the weights resulting from the balancing exercise are used in a regression where the relevant measure of capital flows is the dependent variable and the IMF program dummy is the main explanatory variable; the coefficient of the latter provides an estimate of the ATT. Following Balima \& Sy (2019) and Balima (2017), in different specifications of the model, we also add the covariates used for the balancing in the second step, as well as country and time fixed effects, to take into account the panel dimension of the dataset and increase the efficiency of the estimates.

In the most complete version of our model, we estimate the following regression:

$$
K F_{i t}=\sum_{k=1}^{K} \gamma_{k} C O V_{k i t-1}+\beta I M F_{i t-1}+\alpha_{i}+\delta_{t}+\epsilon_{i t}
$$

where $C O V_{k i t-1}$ are the lagged covariates, $I M F_{i t-1}$ the lagged dummy variable accounting for the presence of an IMF program, $\alpha_{i}$ the country fixed effects and $\delta_{t}$ the time fixed effects. 
For robustness check, we compare our baseline results with those obtained using more conventional approaches, such as the propensity score matching and the inverse propensity score weighting. The propensity score matching procedure estimates for each unit of observation its probability of receiving the treatment (i.e the propensity score) and pairs treated variables with untreated ones that have a similar propensity score. The inverse probability weighted regression adjustment (IPWRA) uses weighted regression coefficients to compute averages of treatment-level predicted outcomes, where the weights are the estimated inverse probabilities of treatment.

\subsection{Outcome variable: Capital flows}

In our analysis we focus on private capital flows, that is we exclude financial flows related to the public sector of the assisted countries, including resources provided by other international financial institutions (such as Multilateral Development Banks or Regional Financing Arrangements) or bilateral donors. In order to do so, we subtract from portfolio outflows and other investment inflows, the components regarding General Government and the Central bank. We look at gross inflows (net incurrence of liabilities by residents, according to the balance of payment BPM6 classification), gross outflows (net acquisition of financial assets by residents) and net inflows (gross inflows minus gross outflows).

\subsection{Treatment variable: IMF programs}

Our variable of interest is a dummy which takes value 1 if the country is under an IMF program in a given quarter. We call this variable "IMF traditional" when considering non-precautionary SBA and "IMF precautionary" when considering FCL, PLL and precautionary SBA. The latter arrangements are requested when recipient countries do not intend to draw on approved amounts, but want to retain the option to do so should they need it. The decision whether the arrangement is precautionary or not is made ex ante and is not related to the evolution of the program. Precautionary SBA are an increasingly important component of the IMF toolkit, and in fact in our country-quarter dataset around 30 percent of all SBA country-quarter observations refer to precautionary SBA. In this analysis we pool the precautionary SBA with the precautionary facilities tout court, such as the Flexible Credit Line (FCL) and the Precautionary Liquidity Line (PLL). ${ }^{13}$

\footnotetext{
${ }^{13} \mathrm{FCL}$ is designed to give to (pre-qualified) countries with very strong policy frameworks and track records in economic performance access to a large (uncapped) amount of resources that can be drawn upfront, without additional conditions attached to them. Countries with very strong economic fundamentals and policy track records can apply for the FCL when faced with potential or actual balance of payments pressures. Qualified countries have flexibility to draw on the credit line at any time within a pre-specified period (one or two years); the access to IMF resources is upfront (without disbursements in tranches) and does not imply additional conditionality, given the strength of the policy frameworks of the eligible countries; there is no cap on access to IMF resources, and the need for resources is assessed on a case-by-case basis by the Executive Board. PLL is meant to give precautionary support to countries with sound fundamentals but with some remaining vulnerabilities; it has a shorter duration and a lower resource access than the FCL.
} 
The consideration of precautionary SBA along with precautionary facilities, represents a novelty with respect to most of the previous literature. This choice has two advantages: first, it increases the number of observations available for precautionary facilities, including the experience of more countries than just the five FCL and PLL users and, second, it allows us to give a different treatment to countries that resort to SBA for potential instead of actual balance of payments crisis, since the two situations may have a different impact on the capital flows directed to the underlying country. ${ }^{14}$

\section{Results}

In this section we present the results of the impact on private capital flows as percentage of GDP (specifically, private gross inflows, private gross outflows and net private inflows) of non-precautionary SBA (variable Traditional IMF) and precautionary facilities such as FCL, PLL and precautionary SBA (variable Precautionary IMF).

As mentioned, the entropy balancing method allows to create a synthetic counterfactual against which assessing the impact of IMF programs on capital flows. Table 4 shows the sample means and variances for the treated and control groups of all matching covariates for country-quarter observations before the balancing procedure. These pre-weighting descriptive statistics reveal that the economic, political and financial conditions in countries with a SBA are characterized by (a) a lower GDP growth, (b) a higher inflation, (c) a lower reserves-to-GDP ratio, (d) a lower current account balance-to-GDP ratio, (e) a lower (worse) political risk rating, (f) a higher level of de jure restrictions to capital flows, (g) a lower trade openness; in addition, observations related to program countries feature a higher VIX and a lower Fed Fund interest rate. Table 5 reports the sample means and variances of matching covariates after weighting in the synthetic control group obtained from entropy balancing. Comparing the average realizations of the pretreatment characteristics of the treatment group to those of the synthetic control group reveals the efficacy of entropy balancing. All covariates are virtually perfectly balanced $;{ }^{15}$ consequently, we can be confident that the control group in the subsequent empirical analysis is comprised of credible counterfactuals for the sample of country-quarter observations subject to IMF programs. $^{16}$

Following Balima \& Sy (2019) and Balima (2017), we present the results for different specifications of the second step regressions (after rebalancing), according to the controls included in addition to the treatment dummy variable. Adding the covariates in the second

\footnotetext{
${ }^{14}$ Since its introduction in 2009, FCL has been used by just three countries (Mexico, Poland and Colombia) for a continuous period of time up to the end of our sample (2019Q3) for Colombia and Mexico and up to November 2017 for Poland. PLL has so far been used only by two countries (Morocco and Macedonia).

${ }^{15}$ The perfect correspondance of means and variances across the two groups after weighting depends also on rounding at the second digit. Considering more digits small differences across groups remain.

${ }^{16}$ In the balancing algorithm the weighted control group is built excluding those country-quarter observations that have another type of IMF program ongoing (such as precautionary programs or Extended Fund Facilities or facilities from the Poverty Reduction and Growth trust).
} 
step increases the efficiency of the estimates, while adding country and time fixed effects allows taking into consideration the panel dimension of our dataset. ${ }^{17}$ Table 6 shows the SBA coefficients for the regressions where the dependent variable is in turn private gross inflows, private gross outflows and net private inflows (i.e. inflows minus outflows). In the first column regressions only the SBA dummy is included; in column 2 we add the balancing covariates as controls; in the third, we add time fixed effects on top of the covariates; in the fourth column, we further add country fixed effects.

For private inflows, the result is strong and robust: irrespective of the specification, the estimated effect of IMF (non-precautionary) programs on private gross inflows is negative and statistically significant, with a magnitude ranging from -5 to -6.5 percent of GDP. The coefficient is equal to -0.064 in our preferred specification that controls for the covariates, as well as quarter and country fixed effects. When the dependent variable is private gross outflows, it turns out that the coefficient of our variable of interest is still negative, but lower in absolute value (0.027) compared to outflows; this result suggests that residents tend to reduce outflows or to repatriate capital from abroad, providing evidence of some catalytic effect.

Like Erce \& Riera-Crichton (2015) we find that foreign and domestic investors react differently to IMF programs; the former tend to reduce drastically their exposures towards program countries while residents are more likely to repatriate their foreign assets, partly offsetting the reduction of inflows.

In the regressions regarding net private inflows we still find a negative and significant coefficient for the treatment variable. Note that the effect on net inflows depends on the sign and the magnitude of the coefficients for gross inflows and outflows; in this case, given that the coefficient related to inflows is relatively higher, we find that the anticatalytic effect associated with foreign investors prevails over the catalytic effect associated with domestic investors. Overall these findings (table 6) provide evidence that traditional IMF programs have an anticatalytic effect on both gross and net inflows.

When looking at the impact of traditional IMF programs on different types of inflows, we find that the anticatalytic effect can be mainly ascribed to the reduction of portfolio and other investment inflows, while the impact of IMF programs on FDI is relatively weaker though significant at 10 percent level. (see table 7 ). ${ }^{18}$

These findings partly overlap with those found by Diaz-Cassou et al. (2006), according to which IMF programs are associated with an anticatalytic effect for banking flows, like in our analysis, while they would not affect portfolio investments. However it is worth considering that their analysis covers programs approved in the period 1970-2002, and that the weight of portfolio investments as external funding source, in particular for emerging economies, has increased significantly over time, mostly after the Global Financial Crisis (EgurenMartin et al. (2020)). From this perspective, our study suggests that IMF programs may

\footnotetext{
${ }^{17}$ According to Neuenkirch \& Neumeier (2016), including covariates employed in the first step of entropy balancing in the regression step is similar to introducing control variables in a randomized experiment.

${ }^{18}$ In this case, for sake of simplicity, we just present our preferred specification, namely the one including covariates, time and country effects in the second-step regression.
} 
have a significant impact on the behavior of a wider range of investors, relative to previous studies which focus on banking flows (Erce \& Riera-Crichton (2015)).

Table 8 shows the same analysis repeated for the precautionary programs. ${ }^{19}$ We find evidence of a catalytic effect on gross outflows, while the effect on gross inflows is smaller and not significant. The impact on net flows is positive and significant since the effect on outflows prevails over that on inflows, whereas the opposite occurs in the case of traditional programs. Note that while our approach to look into both inflows and outflows separately is similar to Erce \& Riera-Crichton (2015), the distinction between precautionary and traditional programs allows us to highlight their different impact on net flows.

These findings are in line with those obtained by Diaz-Cassou et al. (2006) regarding traditional programs used as precautionary facilities before 2002. In this regard, our analysis provides further evidence on the success of precautionary programs, since it covers arrangements approved after 2002 (see footnote 4), including precautionary facilities, such as the PLL and FCL which were introduced after the Global Financial Crisis.

In order to shed light on the relevance of the selection bias, we also run a standard panel regression with time fixed effects and robust standard errors for (non-precautionary) SBA and precautionary programs, for sake of comparison with our results. The results of the panel regression show a much stronger anticatalytic effect for SBA, with an average quarterly reduction of 9.4 percent of the GDP in gross inflows (against 6.4 percent in the entropy balancing model), and a reduction of 4 percent of the GDP in net inflows (against 3.5 percent), while the effect on outflows is no significant (table 9). With regard to precautionary programs, while we find evidence of catalytic effect on gross outflows and net inflows using the entropy balancing models, the results of the panel regression show no significant impact, confirming that the selection bias tends to underestimate the effect of IMF programs (table 10).

\subsection{The cases of exceptional access and off-track programs}

As we argued in the previous sections, the attitude of private investors towards countries under IMF programs hinges on several factors; in this section, building on previous works on the catalytic role of the IMF, we look into some of these factors, namely the size of IMF loans (Benelli (2003)) and the degree of compliance with program conditionality (Edwards (2005)). With regard to the former, we interact our variable of interest ("IMF traditional") with a dummy identifying programs exceeding normal access limits (exaccess), to disentangle the effects of IMF programs for countries with very large financial needs. Table 11 shows the coefficients of interaction for inflows, outflows and net flows respectively. ${ }^{20} \mathrm{We}$ find that exceptional access programs have a negative and strongly significant marginal

\footnotetext{
${ }^{19}$ In this case the balancing is done only on the first moments of the distributions of the covariates in the treated and control group, because it was not possible to find a balance on the first two moments. Note that both Balima \& Sy (2019) and Balima (2017) perform entropy balance on the first moments only.

${ }^{20}$ In this section we use the model specification including covariates country and time effects in the second step regression.
} 
impact on net inflows, while the coefficient of our variable of interest is no longer significant. This result suggests that the anticatalytic effect we find in the baseline regression with regard to all SBA, may be ascribed to a large extent to exceptional access programs. By comparing these estimates with those illustrated above associated with the baseline regression (table 6), we notice that for outflows the coefficient of our variable of interest is much higher in absolute value, suggesting that when the size of IMF loans does not exceed normal access limits, residents tend to repatriate more capital from abroad.

With the aim of providing further evidence on the size of IMF financial assistance, we conduct a few additional tests; first, we run the baseline regression for private gross inflows excluding exceptional access programs from our sample. It turns out that the coefficient of the variable of interest for gross inflows falls from -0.064 to -0.021, while the impact on net inflows is no longer significant (see table 12); these findings corroborate the thesis that the anticatalytic effect associated with traditional IMF programs is mostly due to exceptional access programs.

As second test, instead of identifying large programs according to IMF exceptional access policy, we rank programs, by using the ratio of total access to GDP. Then we use different percentiles $(50,75,90,95)$ of this ratio to explore whether the effects of IMF programs on net inflows vary along the distribution of the size of the loans (table 13). It turns out that the impact of the size of IMF loans on net inflows is always negative for programs above the median, and that the magnitude increases as we move towards larger programs; however the negative effect related to the size of IMF loans, becomes strongly significant only for programs above the 90th percentile. This finding is not surprising given that the main criterion for defining exceptional access is the ratio of total access on countries' quotas which are largely based on the respective GDP; it is also in line with Krahnke (2020) which finds that programs whose size is in the highest quantile, may be associated with anticatalytic effects.

Why exceptional access programs are associated with anticatalytic effects? Mody \& Saravia (2003) argue that large IMF loans may prove counterproductive if investors fear that program countries will become insolvent; in fact, in case of restructuring, the seniority of the IMF entails for junior creditors that the loss given default is higher, the bigger the size of IMF loan. To explore this hypothesis we slightly change our model focusing on exceptional access programs as treatment group and controlling for the level of public debt. We first run regressions with the same confounding factors used in previous regressions and the dummy exaccess denoting exceptional access programs as variable of interest. Then, we repeat the exercise including the ratio of public debt to GDP among the confounding factors (table 14). With regard to net inflows the coefficients of the variable of interest is no longer significant when we control for the public debt suggesting that the anticatalytic effect associated with exceptional access programs is linked to insolvency risks. When we 
look into gross inflows, we find that the anticatalytic effect related to foreign investors is attenuated if we account for the level of public debt. As regards outflows, the coefficient of our variable of interest increases, suggesting that domestic investors would repatriate more funds from abroad, the level of public debt being equal. Overall, these findings confirm that large IMF loans may have anticatalytic effects for highly indebted countries.

Our findings provide further evidence on the importance of country fundamentals for the success of IMF programs (Mody \& Saravia (2003)); with regard to debt sustainability, our results are also in line with van der Veer \& de Jong (2013), which find that countries that become insolvent after the approval of IMF programs, tend to experience anticatalytic effects.

Another aspect to take into account is the compliance with IMF conditionality. Using a before-after approach, IRC (2019) highlight that countries associated with off-track programs, tend to experience a larger decrease of capital inflows relative to other program countries. In order to dig deeper on this aspect, we interact our variable of interest with a dummy denoting programs that went off-track, i.e. those having less than half of the scheduled reviews completed. ${ }^{21}$ Table 15 shows that anticatalytic effects are compounded when IMF programs go off-track, suggesting that failing to comply with IMF conditionality is one of the main reasons why IMF programs may be associated with anticatalytic effects. This finding corroborates the results by Edwards (2005), according to which the suspension of programs following the breaching of IMF conditionality, is associated with portfolio flights.

\section{Robustness checks}

Our baseline model, presented above, suggests that non-precautionary SBA under certain conditions may have an anticatalytic effect on capital flows, while precautionary programs have a catalytic effect. In what follows we present a set of robustness checks to verify whether our findings depend on the methodology employed. We use different approaches to address the selection bias, namely the propensity score matching and propensity score weighting. Propensity score matching estimates the average treatment effect on the treated (ATT) by comparing the average level of the outcome variable (capital flows) between the group of treated observations and a group of untreated matched to the treated ones with respect to their similarity in terms of the probability of undergoing the treatment (i.e. the propensity score). This method is largely used in the literature on the effects of IMF programs (Bal Gunduz (2016) and Chapman et al. (2015)) and also in the literature on capital flows (Forbes et al. (2015)). In this case, we estimate the ATT for non-precautionary SBA and for precautionary programs such as FCL, PLL and precautionary SBA with a nearest

\footnotetext{
${ }^{21}$ The same definition is used in other studies on IMF conditionality. See for example IRC (2019). This classification applies during the whole period of implementation, regardless the date since which programs have gone off track.
} 
neighbor algorithm ${ }^{22}$. The resulting ATTs, shown in table 16, broadly confirm the main findings of our model, with an anticatalytic effect for traditional programs and a catalytic effect for precautionary programs.

As a further check we use a propensity matching approach, in particular the inverseprobability-weighted regression adjustment estimator (IPWRA). IPWRA estimators use a model to predict the treatment status and another model to predict the outcome, to allow a comparison between the two. The procedure involves three-steps: (1) estimating the parameters of the treatment model and computing the inverse-probability weights; (2) using the estimated inverse-probability weights, fitting weighted regression models of the outcome for each treatment level and obtain the treatment-specific predicted outcomes for each subject; (3) computing the means of the treatment-specific predicted outcomes. The difference of these averages provides the estimates of the average treatment effect, as reflected in table 17 . Our results broadly keep holding also with this methodology.

\subsection{Other issues}

In order to study whether the size and the sign of catalytic effects change over time, we interact our variable of interest with dummy variables identifying respectively the first 4 and the last 4 quarters of duration of IMF programs. As regards the first four quarters of a SBA, table 18 shows an asymmetry between foreign and domestic investors, as the interaction term is negative for both inflows and outflows. On one hand, foreign investors seem to retrench from program countries mostly during the starting phase; on the other hand, domestic investors cut their investments abroad, which might be interpreted as a return of confidence in their home country. If we repeat the same test with regard to the last four quarters, the interaction term is not significant suggesting that the size of catalytic effects does not vary towards the end of IMF programs (table 19).

An objection to our findings might be that the evidence of reduction in capital inflows we find in the baseline regression reflects indeed the fact that during the implementation of IMF programs borrowing countries have less need to tap financial markets to cover their financial needs. In order to address this point, we analyze the impact of IMF traditional programs on private capital flows, subtracting from private capital inflows the value of inward investments in government bonds. Table 21 shows that our results, as regards the anticatalytic effects associated with traditional programs hold even when we subtract from inflows the value of government bonds purchased by foreign investors. For both private gross inflows and portfolio inflows, as expected, the coefficient of our variable

\footnotetext{
${ }^{22}$ The algorithm considers the nearest five neighbors within a caliper of 0.01 percent deviation in the propensity score, with replacement. We do not show statistics on the balance after matching but we check that they are satisfactory, according to the indications of Rosenbaum \& Rubin (1985). For estimating the propensity score, we use a Logit model with the same covariates as in the entropy balance baseline model.
} 
of interest decreases relative to our baseline results, but it remains negative and significant.

In the baseline analysis regarding traditional IMF programs we focused on Stand-by Arrangements (SBA), excluding Extended Fund Arrangements (EFF). EFF are meant for countries with serious medium-term balance of payments problems due to structural weaknesses; compared with SBA, they generally feature a longer program engagement and a longer repayment period. ${ }^{23}$ If we pool our SBA and EFF we find evidence of anticatalytic effect for gross inflows but not for net inflows, while the analysis does not yield significant coefficients for EFF alone. This may be due to the longer duration of the EFF, which makes average results not significant (periods of higher capital flows may balance out periods of lower flows).

Finally, since multiple arrangements for single countries are not the exception in the IMF lending history (see IRC, 2019), we conducted another test to explore the relevance of serial borrowers. In particular we interact our variable of interest with a dummy identifying successor programs, that are those approved for countries which had already been supported by the Fund during the period under observation. As table 20 shows, we find that these programs have an additional negative impact only on gross inflows. This result suggests that foreign investors are reluctant to invest in countries which underwent previous IMF programs, presumably because they call into question the ability of countries to put through the agenda of reforms needed to restore external viability, as suggested by Mody \& Saravia (2003).

\section{Conclusions}

In this paper, we focus on the catalytic effects of IMF programs, namely we investigate whether the intervention of the Fund increases the propensity of private investors to lend to program countries. Since the objective of IMF programs is not to fill the financing gap of countries undergoing a balance of payments crisis, but to help them restore external viability, the catalytic effect represents a crucial ingredient for the success of IMF programs. The main results of this study are: i) for net inflows, Stand-by Arrangements are associated with an anticatalytic effect, whereas precautionary programs are associated with a catalytic effect; ii) the anticatalytic effect concerns mainly other investments, while portfolio investments and FDI prove less responsive; iii) exceptional access programs are associated with a strong anticatalytic effect which is correlated with the level of public debt; for programs within normal access limits, the impact is smaller and significant only on gross inflows;

\footnotetext{
${ }^{23} \mathrm{EFF}$ provide assistance to countries: (i) experiencing serious payment imbalances because of structural impediments; or (ii) characterized by slow growth and an inherently weak balance of payments position. Under an EFF, the conditionality featured in the adjustment program is expected to have a strong focus on structural reforms to address institutional or economic weaknesses, in addition to the maintenance of macroeconomic stability. The borrowing limits are the same as for the SBA (cumulatively up to 435 percent of a member's quota) but the duration is longer (up to four years, instead of three) and so is the repayment period (4.5 to 10 years, instead of 3 to 5 years).
} 
iv) anticatalytic effects are stronger for programs featuring a low level of compliance with IMF conditionality (off-track).

To sum up, we find evidence of catalytic effects for precautionary programs; with respect to traditional programs, the ability of the IMF to stimulate private financial flows towards program countries is called into question, in particular for exceptional access programs and when countries have trouble complying with IMF conditionality.

The policy implications of our findings are threefold. First, it is crucial to enhance the ownership of SBA by assisted countries to reinforce the credibility of the implementation of the adjustment programs. Second, for exceptional access programs, it is paramount to ensure that debt is sustainable, in order to prevent anticatalytic effects. Third, the recourse to precautionary facilities should be promoted in a carefully targeted way, balancing the aim of preventing liquidity crises with the need to avoid immobilizing too large a share of IMF resources. In this regard, the decision of the IMF to introduce a new precautionary facility, the Short-term Liquidity Line (SLL), taken in April 2020 in response to the coronavirus pandemic, is a step in the right direction. ${ }^{24}$

\footnotetext{
${ }^{24}$ The SLL is designed to be a liquidity backstop for members with very strong policy frameworks and fundamentals, who face potential, moderate, short-term liquidity needs because of external shocks that generate balance of payment difficulties.
} 
Table 1: Data description and sources

\begin{tabular}{lll}
\hline \multicolumn{1}{c}{ Variable name } & Description & Source \\
\hline GROSS_INFLOWS & Net incurrence of liabilities & IMF BOPS \\
GROSS_OUTFLOWS & Net acquisition of assets & IMF BOPS \\
NET_INFLOWS & Gross inflows less gross outflows & IMF BOPS \\
GDP & Gross Domestic Product at current prices & IMF IFS \\
growth & Real GDP growth & IMF IFS \\
inflation & Inflation rate & IMF IFS \\
reserves & Stock of international reserves & IMF IFS \\
CA_bal & Current account balance & IMF IFS \\
PoliticalRiskRating & Composite index of political risk & ICRG PRS Group \\
ka & Index of capital account restrictions & Fernandez (2016) \\
openness & Imports plus exports scaled by GDP & IMF IFS \\
VIX & Market volatility index & CBOE \\
FedFundRate & Overnight interest rate on US Federal funds & FRED St.Louis Fed \\
IMF traditional & Non-precautionary SBA & MONA IMF \\
IMF precautionary & FCL, PCL, PLL and precautionary SBA & MONA IMF \\
\hline
\end{tabular}

Table 2: Summary statistics

\begin{tabular}{lccccc}
\hline \multicolumn{1}{c}{ Variable } & Mean & Std. Dev. & Min. & Max. & N \\
\hline growth & 3.862 & 4.411 & -10.67 & 19.59 & 14363 \\
inflation & 5.667 & 7.405 & -3.259 & 46.101 & 14314 \\
reserves_onGDP & 0.741 & 0.743 & 0.014 & 4.355 & 13940 \\
CA_bal_onGDP & -0.023 & 0.111 & -0.366 & 0.369 & 13802 \\
PoliticalRiskRating & 66.480 & 12.795 & 35 & 92.333 & 10099 \\
ka & 0.37 & 0.335 & 0 & 1 & 6800 \\
openness & 0.871 & 0.521 & 0.215 & 3.518 & 13786 \\
VIX & 19.737 & 8.1 & 9.450 & 45.45 & 14550 \\
FedFundRate & 1.751 & 1.969 & 0.06 & 6.51 & 14550 \\
\hline
\end{tabular}

Table 3: Correlation table

\begin{tabular}{|c|c|c|c|c|c|c|c|c|c|}
\hline & growth & inflation & reserves & CAbalance & PRR & ka & openness & VIX & FedFundRate \\
\hline Inflows & $0.051^{* * *}$ & $-0.051^{* * *}$ & 0.008 & $-0.032^{* *}$ & $0.266^{* * *}$ & $-0.152^{* * *}$ & $0.357^{* * *}$ & $-0.041^{* * *}$ & $0.065^{* * *}$ \\
\hline Outflows & 0.015 & $-0.059^{* * *}$ & 0.003 & $0.117^{* * *}$ & $0.293^{* * *}$ & $-0.166^{* * *}$ & $0.370^{* * *}$ & $-0.042^{* * *}$ & $0.062^{* * *}$ \\
\hline Net inflows & $0.131^{* * *}$ & $0.027^{*}$ & $0.027^{* *}$ & $-0.520^{* * *}$ & $-0.099^{* * *}$ & $0.044^{* *}$ & $-0.078^{* * *}$ & 0.002 & $0.029^{* *}$ \\
\hline IMF traditional & $-0.056^{* * *}$ & -0.002 & -0.008 & $-0.028^{* *}$ & $-0.042^{* * *}$ & $0.038^{* *}$ & $-0.027^{* *}$ & $0.046^{* * *}$ & $-0.075^{* * *}$ \\
\hline IMF precautionary & -0.007 & -0.002 & -0.005 & 0.003 & $-0.032^{* *}$ & 0.003 & $-0.034^{* * *}$ & $-0.032^{* * *}$ & $-0.030^{* * *}$ \\
\hline
\end{tabular}


Figure 1: IMF programs in the sample

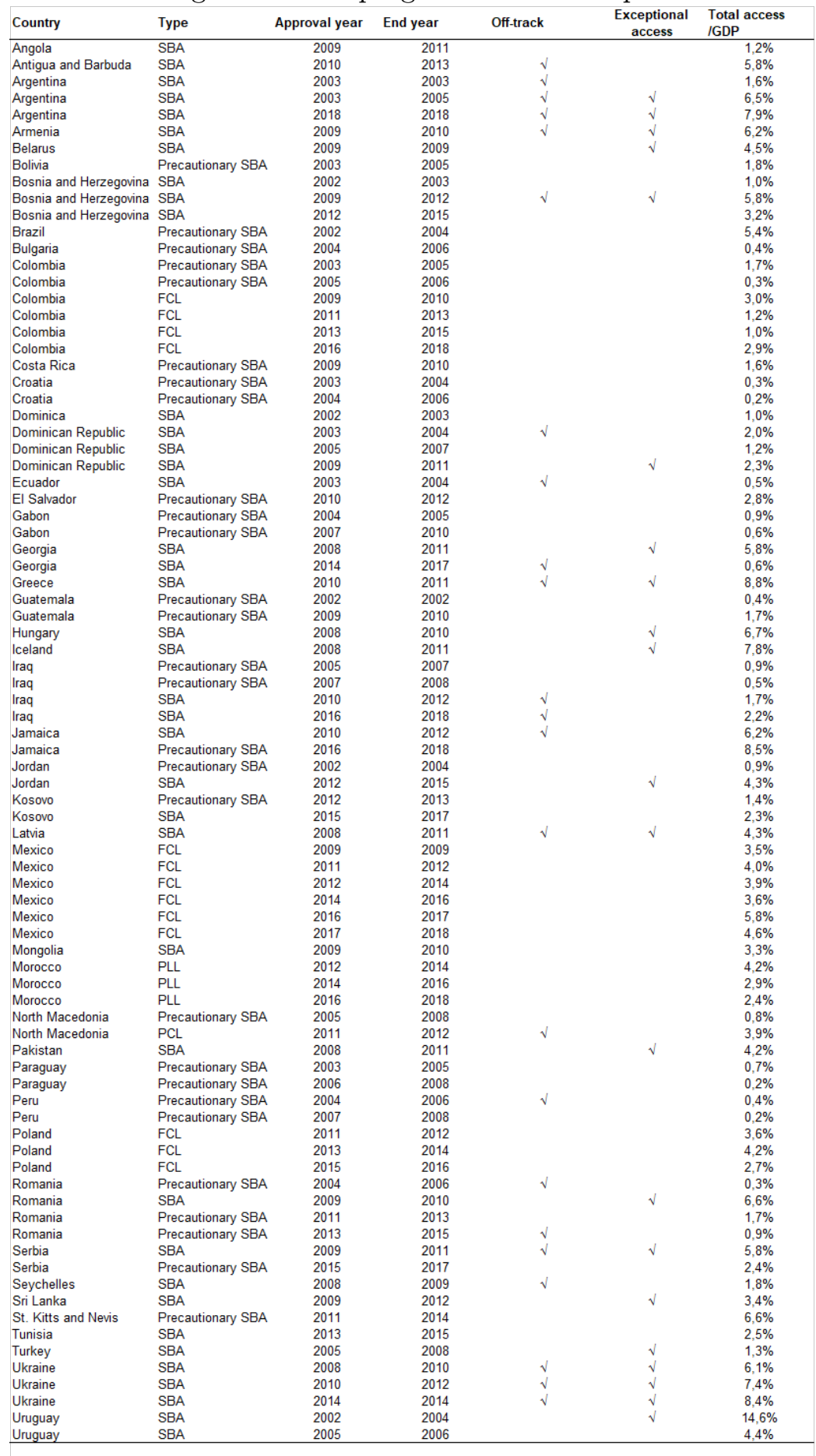


Table 4: Descriptive statistics before weighting

\begin{tabular}{|c|c|c|c|c|}
\hline & \multicolumn{2}{|c|}{ Treated } & \multicolumn{2}{|c|}{ Control } \\
\hline & Mean & Variance & Mean & Variance \\
\hline growth & 1.89 & 33.36 & 3.87 & 14.91 \\
\hline inflation & 9.36 & 59.81 & 5.37 & 49.3 \\
\hline reserves_onGDP & 0.60 & 0.14 & 0.71 & 0.59 \\
\hline CA_bal_onGDP & -0.028 & 0.03 & 0.006 & 0.008 \\
\hline PoliticalRiskRating & 65.48 & 67.77 & 69.87 & 155.3 \\
\hline $\mathrm{ka}$ & 0.48 & 0.12 & 0.34 & 0.10 \\
\hline openness & 0.70 & 0.09 & 0.85 & 0.32 \\
\hline VIX & 22.07 & 87.27 & 20.42 & 65.57 \\
\hline FedFundRate & 1.08 & 2.59 & 1.88 & 4.34 \\
\hline
\end{tabular}

Table 5: Descriptive statistics after weighting

\begin{tabular}{l|cc|cc}
\hline & \multicolumn{2}{|c}{ Treated } & \multicolumn{2}{c}{ Control } \\
& Mean & Variance & Mean & Variance \\
\hline growth & 1.89 & 33.36 & 1.89 & 33.36 \\
inflation & 9.36 & 59.81 & 9.36 & 59.81 \\
reserves_onGDP & 0.60 & 0.14 & 0.60 & 0.14 \\
CA_bal_onGDP & -0.028 & 0.03 & -0.028 & 0.03 \\
PoliticalRiskRating & 65.48 & 67.77 & 65.48 & 67.77 \\
ka & 0.48 & 0.12 & 0.48 & 0.12 \\
openness & 0.70 & 0.09 & 0.70 & 0.09 \\
VIX & 22.07 & 87.27 & 22.07 & 87.27 \\
FedFundRate & 1.08 & 2.59 & 1.08 & 2.59 \\
\hline
\end{tabular}

Table 6: Impact of IMF traditional arrangements on private flows

\begin{tabular}{|c|c|c|c|c|}
\hline & $(1)$ & $(2)$ & $(3)$ & $(4)$ \\
\hline \multicolumn{5}{|c|}{ Dependent variable: Gross inflows on GDP } \\
\hline IMF traditional & $-0.0512^{* * *}$ & $-0.0496^{* * *}$ & $-0.0559^{* * *}$ & $-0.0642^{* * *}$ \\
\hline$R^{2}$ & 0.03 & 0.14 & 0.22 & 0.33 \\
\hline \multicolumn{5}{|c|}{ Dependent variable: Gross outflows on GDP } \\
\hline IMF traditional & $-0.0203^{*}$ & $-0.0192^{*}$ & $-0.0176^{*}$ & $-0.0269 * *$ \\
\hline$R^{2}$ & 0.01 & 0.02 & 0.10 & 0.19 \\
\hline \multicolumn{5}{|c|}{ Dependent variable: Net inflows on GDP } \\
\hline IMF traditional & $-0.0251^{* *}$ & $-0.0248^{* * *}$ & $-0.0332^{* * *}$ & $-0.0351^{* * *}$ \\
\hline$R^{2}$ & 0.02 & 0.18 & 0.27 & 0.36 \\
\hline Observations & 4775 & 4775 & 4775 & 4775 \\
\hline Covariates in 2nd step & No & Yes & Yes & Yes \\
\hline Time FE in 2nd step & No & No & Yes & Yes \\
\hline Country FE in 2nd step & No & No & No & Yes \\
\hline
\end{tabular}

$$
{ }^{* * *} \mathrm{p}<0.01,{ }^{* *} \mathrm{p}<0.05,{ }^{*} \mathrm{p}<0.1
$$

The variable $I M F$ traditional is a (lagged) dummy for IMF non precautionary SBA.

The (lagged) covariates included in the analysis are GDP growth, trade openness, CA balance on GDP, inflation, FX reserves on GDP, Political Risk Rating, KA index for capital controls, VIX index, Fed funds interest rate. 
Table 7: Effects of SBA on inflows components

\begin{tabular}{lcccc}
\hline \multirow{2}{*}{ VARIABLES } & Total inflows & Other investment inflows & FDI & Portfolio inflows \\
\hline \multirow{2}{*}{ IMF traditional } & $-0.0642^{* * *}$ & $-0.0362^{* * *}$ & $-0.0161^{*}$ & $-0.0188^{* * *}$ \\
& $(0.01)$ & $(0.01)$ & $(0.01)$ & $(0.00)$ \\
& & & & \\
Observations & 4775 & 4295 & 4740 & 4557 \\
$R^{2}$ & 0.33 & 0.32 & 0.11 & 0.29 \\
\hline
\end{tabular}

$$
\text { *** } \mathrm{p}<0.01, * * \mathrm{p}<0.05, * \mathrm{p}<0.1
$$

The variable IMF traditional is a (lagged) dummy for IMF non precautionary SBA.

The second step regression includes time FE, country FE and the following (lagged) covariates: GDP growth, trade openness, CA balance on GDP, inflation, FX reserves on GDP, Political Risk Rating, KA index for capital controls, VIX index, Fed funds interest

Table 8: Impact of precautionary arrangements on private flows

\begin{tabular}{|c|c|c|c|c|}
\hline & (1) & $(2)$ & $(3)$ & (4) \\
\hline \multicolumn{5}{|c|}{ Dependent variable: Gross inflows on GDP } \\
\hline IMF precautionary & $-0.0216^{* * *}$ & $-0.0213^{* * *}$ & $-0.0296^{* * *}$ & 0.00155 \\
\hline$R^{2}$ & 0.00 & 0.17 & 0.21 & 0.43 \\
\hline \multicolumn{5}{|c|}{ Dependent variable: Gross outflows on GDP } \\
\hline IMF precautionary & $-0.0382^{* * *}$ & $-0.0379 * * *$ & $-0.0427 * * *$ & $-0.0112^{* *}$ \\
\hline$R^{2}$ & 0.02 & 0.11 & 0.13 & 0.38 \\
\hline \multicolumn{5}{|c|}{ Dependent variable: Net inflows on GDP } \\
\hline IMF precautionary & $0.0173^{* * *}$ & $0.0174^{* * *}$ & $0.0141^{* * *}$ & $0.0134^{* *}$ \\
\hline$R^{2}$ & 0.01 & 0.28 & 0.34 & 0.45 \\
\hline Observations & 4841 & 4841 & 4841 & 4841 \\
\hline Covariates in 2 nd step & No & Yes & Yes & Yes \\
\hline Time FE in 2nd step & No & No & Yes & Yes \\
\hline Country FE in 2nd step & No & No & No & Yes \\
\hline
\end{tabular}

$$
{ }^{* * *} \mathrm{p}<0.01,{ }^{* *} \mathrm{p}<0.05,{ }^{*} \mathrm{p}<0.1
$$

The variable IMF precautionary is a (lagged) dummy for IMF precautionary programs (FCL, PCL, PLL) and precautionary SBA. The (lagged) covariates included in the analysis are GDP growth, trade openness, CA balance on GDP, inflation, FX reserves on GDP, Political Risk Rating, KA index for capital controls, VIX index, Fed funds interest rate. 
Table 9: Fixed effects panel estimation for traditional programs

\begin{tabular}{lccc}
\hline & $(1)$ & $(2)$ & $(3)$ \\
& Gross inflows on GDP & Gross outflows on GDP & Net inflows on GDP \\
\hline growth & 0.00626 & 0.00318 & $0.00315^{* * *}$ \\
inflation & $(0.00425)$ & $(0.00392)$ & $(0.000861)$ \\
& 0.00203 & 0.00189 & 0.000159 \\
reserves_onGDP & $(0.00129)$ & $(0.00119)$ & $(0.000299)$ \\
& 0.0763 & 0.0810 & -0.000169 \\
CA_bal_onGDP & $(0.0911)$ & $(0.0872)$ & $(0.0124)$ \\
& $-0.607^{* * *}$ & -0.310 & $-0.270^{* * *}$ \\
PoliticalRiskRating & $(0.199)$ & $(0.191)$ & $(0.0777)$ \\
& $0.00557^{* *}$ & 0.00338 & $0.00185^{* * *}$ \\
ka & $(0.00213)$ & $(0.00221)$ & $(0.000624)$ \\
& $-0.249^{*}$ & $-0.284^{* *}$ & $0.0493^{* *}$ \\
openness & $(0.144)$ & $(0.127)$ & $(0.0225)$ \\
& -0.0332 & -0.0419 & 0.00294 \\
VIX & $(0.0835)$ & $(0.0742)$ & $(0.0211)$ \\
& -0.0577 & -0.0538 & -0.00210 \\
FedFundRate & $(0.0349)$ & $(0.0340)$ & $(0.0103)$ \\
& 0.102 & 0.0954 & 0.00390 \\
IMF traditional & $(0.0685)$ & $(0.0672)$ & $(0.0192)$ \\
& $-0.0941^{* *}$ & -0.0478 & $-0.0404^{* *}$ \\
$N$ & $(0.0432)$ & $(0.0327)$ & $(0.0163)$ \\
\hline
\end{tabular}

$$
* * * \mathrm{p}<0.01, * * \mathrm{p}<0.05, * \mathrm{p}<0.1
$$

The variable IMF traditional is a (lagged) dummy for IMF non precautionary SBA.

All covariates are lagged. 
Table 10: Fixed effects panel estimation for precautionary programs

\begin{tabular}{lccc}
\hline & $(1)$ & $(2)$ & $(3)$ \\
& Gross inflows on GDP & Gross outflows on GDP & Net inflows on GDP \\
\hline growth & $0.00703^{*}$ & 0.00358 & $0.00347^{* * *}$ \\
inflation & $(0.00415)$ & $(0.00375)$ & $(0.000960)$ \\
& 0.00207 & 0.00191 & 0.000189 \\
reserves_onGDP & $(0.00127)$ & $(0.00117)$ & $(0.000298)$ \\
& 0.0734 & 0.0793 & -0.00117 \\
CA_bal_onGDP & $(0.0912)$ & $(0.0870)$ & $(0.0126)$ \\
& $-0.608^{* * *}$ & -0.311 & $-0.270^{* * *}$ \\
PoliticalRiskRating & $(0.199)$ & $(0.190)$ & $(0.0779)$ \\
& $0.00567^{* * *}$ & 0.00341 & $0.00191^{* * *}$ \\
ka & $(0.00212)$ & $(0.00219)$ & $0.000632)$ \\
& $-0.251^{*}$ & $-0.286^{* *}$ & $0.0495^{* *}$ \\
openness & $(0.147)$ & $(0.128)$ & $(0.0239)$ \\
& -0.0345 & -0.0418 & 0.00155 \\
VIX & $(0.0849)$ & $(0.0752)$ & $(0.0210)$ \\
& -0.0574 & -0.0537 & -0.00189 \\
FedFundRate & $(0.0349)$ & $(0.0340)$ & $(0.0103)$ \\
& 0.101 & 0.0948 & 0.00335 \\
IMF precautionary & $(0.0686)$ & $(0.0673)$ & $(0.0193)$ \\
& -0.00631 & -0.0143 & 0.00898 \\
$N$ & $(0.0220)$ & $(0.0187)$ & $(0.00854)$ \\
\hline
\end{tabular}

$* * * \mathrm{p}<0.01, * * \mathrm{p}<0.05, * \mathrm{p}<0.1$

The variable IMF precautionary is a (lagged) dummy for IMF precautionary programs (FCL, PCL, PLL) and precautionary SBA All covariates are lagged.

Table 11: Exceptional access programs

\begin{tabular}{|c|c|c|c|}
\hline VARIABLES & $\begin{array}{c}(1) \\
\text { Inflows }\end{array}$ & $\begin{array}{c}(2) \\
\text { Outflows }\end{array}$ & $\begin{array}{c}(3) \\
\text { Net inflows }\end{array}$ \\
\hline IMF traditional & $\begin{array}{c}-0.0610^{* *} \\
(0.04)\end{array}$ & $\begin{array}{c}-0.0664^{* * *} \\
(0.04)\end{array}$ & $\begin{array}{c}0.0066 \\
(0.02)\end{array}$ \\
\hline IMF traditional*exaccess & $\begin{array}{c}-0.0042 \\
(0.04)\end{array}$ & $\begin{array}{c}0.0509 \\
(0.04)\end{array}$ & $\begin{array}{c}-0.0538^{* * *} \\
(0.02)\end{array}$ \\
\hline $\begin{array}{l}\text { Observations } \\
R^{2}\end{array}$ & $\begin{array}{l}4775 \\
0.33\end{array}$ & $\begin{array}{l}4775 \\
0.20\end{array}$ & $\begin{array}{l}4775 \\
0.37\end{array}$ \\
\hline
\end{tabular}

The second step regression includes time FE, country FE and the following (lagged) covariates: GDP growth, trade openness, CA balance on GDP, inflation, FX reserves on GDP, Political Risk Rating, KA index for capital controls, VIX index, Fed funds interest 
Table 12: Overview of SBA results excluding exceptional access programs

\begin{tabular}{lccc}
\hline VARIABLES & $\begin{array}{c}(1) \\
\text { Inflows }\end{array}$ & $\begin{array}{c}(2) \\
\text { Outflows }\end{array}$ & $\begin{array}{c}(3) \\
\text { Net inflows }\end{array}$ \\
\hline IMF traditional & $-0.0210^{* *}$ & -0.0166 & -0.0045 \\
& $(0.02)$ & $(0.02)$ & $(0.01)$ \\
& & & \\
Observations & 4651 & 4651 & 4651 \\
$R^{2}$ & 0.36 & 0.33 & 0.50 \\
\hline
\end{tabular}

$$
\text { *** } \mathrm{p}<0.01,{ }^{* *} \mathrm{p}<0.05,{ }^{*} \mathrm{p}<0.1
$$

The variable $I M F$ traditional is a (lagged) dummy for IMF non precautionary SBA.

The second step regression includes time FE, country FE and the following (lagged) covariates: GDP growth, trade openness, CA balance on GDP, inflation, FX reserves on GDP, Political Risk Rating, KA index for capital controls, VIX index, Fed funds interest rate.

Table 13: Impact of IMF programs on net private inflows according to their size

\begin{tabular}{lcccc}
\hline & $(1)$ & $(2)$ & $(3)$ & $(4)$ \\
VARIABLES & Net inflows & Net inflows & Net inflows & Net inflows \\
\hline & & & & \\
IMF traditional & $-0.0294^{* *}$ & $-0.0233^{* *}$ & $-0.0120^{*}$ & $-0.0195^{* *}$ \\
& $(0.01)$ & $(0.01)$ & $(0.01)$ & $(0.01)$ \\
IMF traditional*size50 & -0.00804 & & & \\
& $(0.01)$ & & & \\
IMF traditional*size75 & & -0.0172 & & \\
& & $(0.01)$ & & \\
IMF traditional*size90 & & & $-0.0551^{* * *}$ & \\
& & & $(0.01)$ & \\
IMF traditional*size95 & & & & $-0.0578^{* * *}$ \\
& & & & $(0.01)$ \\
Observations & 4775 & 4775 & 4775 & 4775 \\
$R^{2}$ & 0.37 & 0.37 & 0.38 & 0.38 \\
\hline
\end{tabular}

$$
{ }^{* * *} \mathrm{p}<0.01,{ }^{* *} \mathrm{p}<0.05,{ }^{*} \mathrm{p}<0.1
$$

The variable IMF traditional is a (lagged) dummy for IMF non precautionary SBA. The second step regression includes time FE, country FE and the following (lagged) covariates: GDP growth, trade openness, CA
balance on GDP, inflation, FX reserves on GDP, Political Risk Rating, KA index for capital controls, VIX index, Fed funds interest rate. 
Table 14: Exceptional access and public debt

\begin{tabular}{lcccccc}
\hline VARIABLES & $(1)$ & $(2)$ & $(3)$ & $(4)$ & $(5)$ & $(6)$ \\
& Inflows & Inflows & Outflows & Outflows & Net inflows & Net inflows \\
\hline \multirow{2}{*}{ IMF traditional* ${ }^{*}$ exaccess } & $-0.0841^{* * *}$ & $-0.0672^{* * *}$ & $-0.0387^{*}$ & $-0.0492^{*}$ & $-0.0458^{* * *}$ & -0.0224 \\
& $(0.02)$ & $(0.02)$ & $(0.02)$ & $(0.03)$ & $(0.01)$ & $(0.01)$ \\
public_debt & & $-0.0726^{*}$ & & 0.0318 & & $-0.124^{* * *}$ \\
& & $(0.04)$ & & $(0.06)$ & & $(0.03)$ \\
& & & & & & \\
Observations & 4780 & 4750 & 4780 & 4750 & 4780 & 4750 \\
$R^{2}$ & 0.38 & 0.35 & 0.24 & 0.23 & 0.36 & 0.37 \\
\hline
\end{tabular}

$$
* * * \mathrm{p}<0.01, * * \mathrm{p}<0.05, * \mathrm{p}<0.1
$$

The variable IMF traditional is a (lagged) dummy for IMF non precautionary SBA.

The second step regression includes time FE, country FE and the following (lagged) covariates: GDP growth, trade openness, CA balance on GDP, inflation, FX reserves on GDP, Political Risk Rating, KA index for capital controls, VIX index, Fed funds interest rate.

Table 15: Off-track programs

\begin{tabular}{lccc}
\hline VARIABLES & $(1)$ & $(2)$ & $(3)$ \\
& Inflows & Outflows & Net inflows \\
\hline \multirow{2}{*}{ IMF traditional } & & & \\
& $-0.0400^{* * *}$ & -0.0162 & $-0.0229^{* * *}$ \\
IMF traditional*offtrack & $-0.0685^{* * *}$ & -0.0301 & $-0.0345^{* *}$ \\
& $(0.02)$ & $(0.02)$ & $(0.02)$ \\
& & & \\
Observations & 4775 & 4775 & 4775 \\
$R^{2}$ & 0.33 & 0.19 & 0.37 \\
\hline
\end{tabular}

$$
* * * \mathrm{p}<0.01, * * \mathrm{p}<0.05, * \mathrm{p}<0.1
$$

The variable $I M F$ traditional is a (lagged) dummy for IMF non precautionary SBA.

The second step regression includes time FE, country FE and the following (lagged) covariates: GDP growth, trade openness, CA balance on GDP, inflation, FX reserves on GDP, Political Risk Rating, KA index for capital controls, VIX index, Fed funds interest rate.

Table 16: Propensity score matching results: ATT

\begin{tabular}{lcc}
\hline & IMF traditional & IMF precautionary \\
\hline Gross inflows & $-0.076^{* * *}$ & -0.011 \\
Gross outflows & $-0.044^{*}$ & $-0.028^{* * *}$ \\
Net inflows & $-0.027^{* *}$ & $0.018^{* * *}$ \\
\hline
\end{tabular}

Nearest neighbor matching with replacement, five neighbors within 0.01 caliper. Bootstrappped standard errors with 1000 repetitions.

*** $\mathrm{p}<0.01, * * \mathrm{p}<0.05,{ }^{*} \mathrm{p}<0.1$ 
Table 17: Inverse probability weighted regression adjustment estimator (IPRWA): ATT

\begin{tabular}{lcc}
\hline & IMF traditional & IMF precautionary \\
\hline Gross inflows & $-0.0741^{* * *}$ & $-0.0124^{* *}$ \\
Gross outflows & $-0.0309^{* *}$ & $-0.0309^{* * *}$ \\
Net inflows & 0.0030 & $0.0176^{* * *}$ \\
\hline \multicolumn{2}{r}{$* * \mathrm{p}<0.01,{ }^{* *} \mathrm{p}<0.05,{ }^{*} \mathrm{p}<0.1$}
\end{tabular}

Table 18: First four quarters of a program

\begin{tabular}{|c|c|c|c|}
\hline VARIABLES & $\begin{array}{c}(1) \\
\text { Inflows }\end{array}$ & $\begin{array}{c}(2) \\
\text { Outflows }\end{array}$ & $\begin{array}{c}(3) \\
\text { Net inflows }\end{array}$ \\
\hline IMF traditional & $\begin{array}{c}-0.0533^{* * *} \\
(0.02)\end{array}$ & $\begin{array}{c}-0.0037 \\
(0.02)\end{array}$ & $\begin{array}{c}-0.0418^{* * *} \\
(0.01)\end{array}$ \\
\hline IMF traditional*first & $\begin{array}{c}-0.0686^{* * *} \\
(0.02)\end{array}$ & $\begin{array}{c}-0.0432^{*} \\
(0.02)\end{array}$ & $\begin{array}{c}-0.0274^{*} \\
(0.02)\end{array}$ \\
\hline Observations & 4775 & 4775 & 4775 \\
\hline$R^{2}$ & 0.36 & 0.17 & 0.38 \\
\hline
\end{tabular}

The second step regression includes time FE, country FE and the following (lagged) covariates: GDP growth, trade openness, CA balance on GDP, inflation, FX reserves on GDP, Political Risk Rating, KA index for capital controls, VIX index, Fed funds interest rate.

Table 19: Last four quarters of a program

\begin{tabular}{|c|c|c|c|}
\hline VARIABLES & $\begin{array}{c}(1) \\
\text { Inflows }\end{array}$ & $\begin{array}{c}(2) \\
\text { Outflows }\end{array}$ & $\begin{array}{c}(3) \\
\text { Net inflows }\end{array}$ \\
\hline IMF traditional & $\begin{array}{c}-0.0929 * * * \\
(0.02)\end{array}$ & $\begin{array}{c}-0.0211 \\
(0.02)\end{array}$ & $\begin{array}{c}-0.0635 * * * \\
(0.01)\end{array}$ \\
\hline IMF traditional*last & $\begin{array}{c}0.0176 \\
(0.03)\end{array}$ & $\begin{array}{c}-0.0208 \\
(0.03)\end{array}$ & $\begin{array}{c}0.0321 \\
(0.02)\end{array}$ \\
\hline $\begin{array}{l}\text { Observations } \\
R^{2}\end{array}$ & $\begin{array}{l}4775 \\
0.35\end{array}$ & $\begin{array}{l}4775 \\
0.16\end{array}$ & $\begin{array}{l}4775 \\
0.38\end{array}$ \\
\hline
\end{tabular}

The second step regression includes time FE, country FE and the following (lagged) covariates: GDP growth, trade openness, CA balance on GDP, inflation, FX reserves on GDP, Political Risk Rating, KA index for capital controls, VIX index, Fed funds interest rate. 
Table 20: Effects of successor programs

\begin{tabular}{lcccccc}
\hline VARIABLES & $\begin{array}{c}(1) \\
\text { Inflows }\end{array}$ & $\begin{array}{c}(2) \\
\text { Inflows }\end{array}$ & $\begin{array}{c}(3) \\
\text { Outflows }\end{array}$ & $\begin{array}{c}(4) \\
\text { Outflows }\end{array}$ & $\begin{array}{c}(5) \\
\text { Net inflows }\end{array}$ & $\begin{array}{c}(6) \\
\text { Net inflows }\end{array}$ \\
\hline IMF & & & & & & \\
successor & $-0.0585^{* *}$ & -0.0411 & -0.0395 & -0.0265 & -0.00556 & 0.000612 \\
& & $-0.0456^{*}$ & & -0.0342 & & -0.0162 \\
Observations & 4867 & 4867 & 4867 & 4867 & 4867 & 4867 \\
$R^{2}$ & 0.24 & 0.24 & 0.18 & 0.18 & 0.26 & 0.26 \\
\hline
\end{tabular}

$$
* * * \mathrm{p}<0.01, * * \mathrm{p}<0.05, * \mathrm{p}<0.1
$$

The variable $I M F$ is a (lagged) dummy for IMF non precautionary SBA and EFF. The variable successor indicates whether the program is not the first of a series of programs.

The second step regression includes time FE, country FE and the following (lagged) covariates: GDP growth, trade openness, CA balance on GDP, inflation, FX reserves on GDP, Political Risk Rating, KA index for capital controls, VIX index, Fed funds interest

$$
\text { rate. }
$$

Table 21: Portfolio and total inflows without the General Government components

\begin{tabular}{lcccc}
\hline VARIABLES & $\begin{array}{c}(1) \\
\text { Portfolio inflows }\end{array}$ & $\begin{array}{c}(2) \\
\text { Portfolio inflows } \\
\text { without general govt. }\end{array}$ & $\begin{array}{c}(3) \\
\text { Gross inflows }\end{array}$ & $\begin{array}{c}(4) \\
\text { Gross inflows } \\
\text { without general govt. }\end{array}$ \\
\hline IMF traditional & $\begin{array}{c}-0.0188^{* * *} \\
(0.00)\end{array}$ & $\begin{array}{c}-0.0106^{* * *} \\
(0.00)\end{array}$ & $\begin{array}{c}-0.0642^{* * *} \\
(0.01)\end{array}$ & $\begin{array}{c}-0.0537^{* * *} \\
(0.01)\end{array}$ \\
Observations & 4557 & 3963 & 4775 & 3963 \\
$R^{2}$ & 0.29 & 0.18 & 0.33 & 0.30 \\
\hline
\end{tabular}

$$
* * * \mathrm{p}<0.01, * * \mathrm{p}<0.05, * \mathrm{p}<0.1
$$

The variable IMF traditional is a (lagged) dummy for IMF non precautionary SBA.

The second step regression includes time FE, country FE and the following (lagged) covariates: GDP growth, trade openness, CA balance on GDP, inflation, FX reserves on GDP, Political Risk Rating, KA index for capital controls, VIX index, Fed funds interest

$$
\text { rate. }
$$




\section{References}

Bal Gunduz, Y. 2016. The economic impact of short-term IMF engagement in low-income countries. World Development, 87, 30-49.

Balima, H. 2017. Do domestic bond markets participation help reduce financial dollarization in developing countries? Economic Modelling, 66, 360-377.

Balima, H., \& Sy, A. 2019. The Impact of Bailouts on the Probability of Sovereign Debt Crises: Evidence from IMF-Supported Programs. IMF working paper no. 2.

Benelli, R. 2003. Do IMF-Supported Programs Boost Private Capital Inflows? the Role of Program Size and Policy Adjustment. IMF Working paper no. 231.

Bird, G., \& Rowlands, D. 2002. Do IMF Programmes Have a Catalytic Effect on Other International Capital Flows? Oxford Development Studies, 30(3), 229-249.

Broner, F., Didier, T., Erce, A., \& Schmukler, S.L. 2013. Gross capital flows: Dynamics and crises. Journal of Monetary Economics, 60(1), 113 - 133. Carnegie-NYU-Rochester Conference.

Chapman, T., Fang, S., Li, X., \& Stone, R.W. 2015. Mixed signals: IMF lending and capital markets. British Journal of Political Science, 47, 329-349.

Corsetti, G., Guimaraes, B., \& Roubini, N. 2003. International lending of last resort and moral hazard: a model of IMF's catalytic finance. NBER Working paper no. 10125.

Cottarelli, C., \& Giannini, C. 2002. Bedfellows, hostages or perfect strangers? Global capital markets and the catalytic effect of IMF crisis lending. IMF working paper no. 193.

Diaz-Cassou, J., Garcia-Herrero, A., \& Molina, L. 2006. What Kind of Capital Flows Does the IMF Catalyze and When? Bank of Spain Working Paper, 0617.

Dreher, A. 2006. IMF And Economic Growth: The Effects Of Programs, Loans, And Compliance With Conditionality. World Development, 34(5), 769-788.

Edwards, M. 2005. Investor Responses to IMF Program Suspensions: Is Noncompliance Costly? Social Science Quarterly, 86, 857-873.

Eguren-Martin, F., Joy, M., Maurini, C., Moro, A., Nispi-Landi, V., Schiavone, A., \& van Hombeeck, C. 2020. Capital flows during the pandemic: lessons for a more resilient international financial architecture. Banca d'Italia Occasional Paper No. 589.

Erce, A., \& Riera-Crichton, D. 2015. A Catalytic IMF? A gross flows approach. Federal Reserve Bank of Dallas, Globalization and Monetary Policy Institute Working paper no. 254. 
Fernandez, A., Klein, M.W., Rebucci, A., Schindler, M., \& Uribe, M. 2016. Capital Control Measures: A New Dataset. IMF Economic Review, 64(3), 548-574.

Forbes, K., Fratzscher, M., \& Straub, R. 2015. Capital-flow management measures: What are they good for? Journal of International Economics, 96(S1), 76-97.

Hainmueller, J. 2012. Entropy balancing for Causal Effects: a multivariate reweighting method to produce balanced samples in observational studies. Political Analysis, 20(1), $25-46$.

Hainmueller, J., \& Xu, Y. 2013. ebalance: a Stata package for entropy balancing. Journal of Statistical Software, 54(7).

IRC. 2019. Conditionality and design of IMF supported programs. ECB Occasional Paper no. 253.

Koepke, R. 2019. What drives capital flows to emerging markets? A survey of the empirical literature. Journal of Economic Surveys, 33(2), 516-540.

Krahnke, T. 2020. Doing More With Less: The Catalytic Function of IMF Lending and the Role of Program Size. Deutsche Bundesbank Discussion Paper No 18/2020.

Kutan, A., Muradoglu, G., \& Sudjana, Brasukra. 2012. IMF programs, financial and real sector performance, and the Asian crisis. Journal of Banking and Finance, 36(01), 164-182.

Mody, A., \& Saravia, D. 2003. Catalyzing capital flows: do IMF-supported programs work as commitment devices? IMF Working paper no. 100.

Neuenkirch, M., \& Neumeier, F. 2016. The impact of US sanctions on poverty. Journal of Development Economics, 121, 110-119.

Rosenbaum, P., \& Rubin, D. 1985. Constructing A Control Group Using Multivariate Matched Sampling Methods That Incorporate The Propensity Score. The American Statistician, 39(1).

Tirole, J. 2002. Financial Crises, Liquidity, and the International Monetary System. Princeton University Press.

van der Veer, K.J.M., \& de Jong, E. 2013. IMF-Supported Programmes: Stimulating Capital to Non-defaulting Countries. The World Economy, 36(4), 375-395.

Zettelmeyer, J. 2000. Can Official Crisis Lending be Counterproductive in the Short Run? Economic Notes, 29(1), 13-29. 


\section{RECENTLY PUBLISHED “TEMI” (*)}

N.1306 - Effects of eligibility for central bank purchases on corporate bond spreads, by Taneli Mäkinen, Fan Li, Andrea Mercatanti and Andrea Silvestrini (November 2020).

N. 1307 - On the design of grant assignment rules, by Francesca Modena, Santiago Pereda Fernandez and Giulia Martina Tanzi (December 2020).

N. 1308 - Monetary policy strategies in the New Normal: a model-based analysis for the euro area, by Fabio Busetti, Stefano Neri, Alessandro Notarpietro and Massimiliano Pisani (December 2020).

N.1309 - Rare disasters, the natural interest rate and monetary policy, by Alessandro Cantelmo (December 2020).

N.1310 - The market stabilization role of central bank asset purchases: high-frequency evidence from the COVID-19 crisis, by Marco Bernardini and Annalisa De Nicola (December 2020).

N.1311 - Equity tail risk in the treasury bond market, by Dario Ruzzi and Mirco Rubin (December 2020).

N. 1312 - Scars of youth non-employment and labour market conditions, by Giulia Martina Tanzi (December 2020).

N. 1313 - The COVID-19 shock and a fiscal-monetary policy mix in a monetary union, by Anna Bartocci, Alessandro Notarpietro and Massimiliano Pisani (December 2020).

N.1314 - Working horizon and labour supply: the effect of raising the full retirement age on middle-aged individuals, by Francesca Carta and Marta De Philippis (February 2021).

N.1315 - Bank credit and market-based finance for corporations: the effects of minibond issuances, by Steven Ongena, Sara Pinoli, Paola Rossi and Alessandro Scopelliti (February 2021).

N. 1316 - Is inflation targeting a strategy past its sell-by date?, by Alberto Locarno and Alessandra Locarno (February 2021).

N.1317 - Declining natural interest rate in the US: the pension system matters, by Jacopo Bonchi and Giacomo Caracciolo (February 2021).

N. 1318 - Can we measure inflation expectations using Twitter?, by Cristina Angelico, Juri Marcucci, Marcello Miccoli and Filippo Quarta (February 2021).

N. 1319 - Identifying deposits'outflows in real-time, by Edoardo Rainone (February 2021).

N. 1320 - Whatever it takes to save the planet? Central banks and unconventional green policy, by Alessandro Ferrari and Valerio Nispi Landi (February 2021).

N. 1321 - The power of text-based indicators in forecasting the Italian economic activity, by Valentina Aprigliano, Simone Emiliozzi, Gabriele Guaitoli, Andrea Luciani, Juri Marcucci and Libero Monteforte (March 2021).

N.1322 - Judicial efficiency and bank credit to firms, by Giacomo Rodano (March 2021).

N.1323 - Unconventional monetary policies and expectations on economic variables, by Alessio Anzuini and Luca Rossi (March 2021).

N. 1324 - Modeling and forecasting macroeconomic dowside risk, by Davide Delle Monache, Andrea De Polis and Ivan Petrella (March 2021).

N. 1325 - Foreclosures and house prices, by Michele Loberto (March 2021).

N.1326 - inancial structure and bank relationships of Italian multinational firms, by Raffaello Bronzini, Alessio D’Ignazio and Davide Revelli (March 2021).

(*) Requests for copies should be sent to:

Banca d'Italia - Servizio Studi di struttura economica e finanziaria - Divisione Biblioteca e Archivio storico - Via Nazionale, 91 - 00184 Rome - (fax 003906 47922059). They are available on the Internet www.bancaditalia.it. 
ALBANESE G., M. CIOFFI and P. TOMMASINO, Legislators' behaviour and electoral rules: evidence from an Italian reform, European Journal of Political Economy, v. 59, pp. 423-444, WP 1135 (September 2017).

Aprigliano V., G. ARDIZZI and L. MONTEFORTE, Using the payment system data to forecast the economic activity, International Journal of Central Banking, v. 15, 4, pp. 55-80, WP 1098 (February 2017).

ARnAudo D., G. MiCUCCI, M. RigON and P. Rossi, Should I stay or should I go? Firms' mobility across banks in the aftermath of the financial crisis, Italian Economic Journal / Rivista italiana degli economisti, v. 5, 1, pp. 17-37, WP 1086 (October 2016).

BASso G., F. D'AMURI and G. PERI, Immigrants, labor market dynamics and adjustment to shocks in the euro area, IMF Economic Review, v. 67, 3, pp. 528-572, WP 1195 (November 2018).

BAtini N., G. MELINA and S. VILlA, Fiscal buffers, private debt, and recession: the good, the bad and the ugly, Journal of Macroeconomics, v. 62, WP 1186 (July 2018).

Burlon L., A. NotARPIETRO and M. PISANI, Macroeconomic effects of an open-ended asset purchase programme, Journal of Policy Modeling, v. 41, 6, pp. 1144-1159, WP 1185 (July 2018).

BUSETTI F. and M. CAIVANO, Low frequency drivers of the real interest rate: empirical evidence for advanced economies, International Finance, v. 22, 2, pp. 171-185, WP 1132 (September 2017).

CAPpelletti G., G. GuAZZAROTTI and P. TOMmasino, Tax deferral and mutual fund inflows: evidence from a quasi-natural experiment, Fiscal Studies, v. 40, 2, pp. 211-237, WP 938 (November 2013).

CARDANi R., A. PACCAGNINI and S. VILLA, Forecasting with instabilities: an application to DSGE models with financial frictions, Journal of Macroeconomics, v. 61, WP 1234 (September 2019).

Chiades P., L. Greco, V. Mengotto, L. Moretti and P. Valbonesi, Fiscal consolidation by intergovernmental transfers cuts? The unpleasant effect on expenditure arrears, Economic Modelling, v. 77, pp. 266-275, WP 1076 (July 2016).

CIANI E., F. DAVID and G. DE BLASIO, Local responses to labor demand shocks: a re-assessment of the case of Italy, Regional Science and Urban Economics, v. 75, pp. 1-21, WP 1112 (April 2017).

CIANI E. and P. FISHER, Dif-in-dif estimators of multiplicative treatment effects, Journal of Econometric Methods, v. 8. 1, pp. 1-10, WP 985 (November 2014).

CIAPANNA E. and M. TABOGA, Bayesian analysis of coefficient instability in dynamic regressions, Econometrics, MDPI, Open Access Journal, v. 7, 3, pp.1-32, WP 836 (November 2011).

Coletta M., R. De Bonis and S. Piermattei, Household debt in OECD countries: the role of supply-side and demand-side factors, Social Indicators Research, v. 143, 3, pp. 1185-1217, WP 989 (November 2014).

Cova P., P. PAgano and M. PISANI, Domestic and international effects of the Eurosystem Expanded Asset Purchase Programme, IMF Economic Review, v. 67, 2, pp. 315-348, WP 1036 (October 2015).

ERCOLANI V. and J. VALLE E AZEVEDO, How can the government spending multiplier be small at the zero lower bound?, Macroeconomic Dynamics, v. 23, 8. pp. 3457-2482, WP 1174 (April 2018).

FERRERo G., M. GROSS and S. NERI, On secular stagnation and low interest rates: demography matters, International Finance, v. 22, 3, pp. 262-278, WP 1137 (September 2017).

FoA G., L. GAMBACORTA, L. Guiso and P. E. Mistrulli, The supply side of household finance, Review of Financial Studies, v.32, 10, pp. 3762-3798, WP 1044 (November 2015).

GERALI A. and S. NERI, Natural rates across the Atlantic, Journal of Macroeconomics, v. 62, article 103019, WP 1140 (September 2017).

GIORDANO C., M. MARINUCCI and A. SILVESTRINI, The macro determinants of firms' and households' investment: evidence from Italy, Economic Modelling, v. 78, pp. 118-133, WP 1167 (March 2018).

Gomellini M., D. PELlEGrinO and F. GIFFONI, Human capital and urban growth in Italy, 1981-2001, Review of Urban \& Regional Development Studies, v. 31, 2, pp. 77-101, WP 1127 (July 2017).

LiBERATI D. and M. LOBERTO, Taxation and housing markets with search frictions, Journal of Housing Economics, v. 46, article 101632, WP 1105 (March 2017).

MAGRI S., Are lenders using risk-based pricing in the Italian consumer loan market? The effect of the 2008 crisis, Journal of Credit Risk, v. 15, 1, pp. 27-65, WP 1164 (January 2018).

Mercatanti A., T. MAKINEN and A. SiLVESTRINI, The role of financial factors for european corporate investment, Journal of International Money and Finance, v. 96, pp. 246-258, WP 1148 (October 2017).

MigliettA A., C. Picillo and M. PIETRUnTI, The impact of margin policies on the Italian repo market, The North American Journal of Economics and Finance, v. 50, WP 1028 (October 2015). 
MONTEFORTE L. and V. RAPONI, Short-term forecasts of economic activity: are fortnightly factors useful?, Journal of Forecasting, v. 38, 3, pp. 207-221, WP 1177 (June 2018).

Neri S. and A. NotArpietro, Collateral constraints, the zero lower bound, and the debt-deflation mechanism, Economics Letters, v. 174, pp. 144-148, WP 1040 (November 2015).

PANCRAZI R. and M. Pietrunti, Natural expectations and home equity extraction, Journal of Housing Economics, v. 46, 4, WP 984 (November 2014).

Pereda FERnANDEZ S., Teachers and cheaters. Just an anagram?, Journal of Human Capital, v. 13, 4, pp. 635-669, WP 1047 (January 2016).

RigGi M., Capital destruction, jobless recoveries, and the discipline device role of unemployment, Macroeconomic Dynamics, v. 23, 2, pp. 590-624, WP 871 (July 2012).

2020

Alessandri P. and M. BotTero, Bank lending in uncertain times, R European Economic Review, V. 128, WP 1109 (April 2017).

Antunes A. and V. ERCOLAnI, Public debt expansions and the dynamics of the household borrowing constraint, Review of Economic Dynamics, v. 37, pp. 1-32, WP 1268 (March 2020).

ARduini T., E. PATACChInI and E. RAInONE, Treatment effects with heterogeneous externalities, Journal of Business \& Economic Statistics, , v. 38, 4, pp. 826-838, WP 974 (October 2014).

Bologna P., A. Miglietta and A. Segura, Contagion in the CoCos market? A case study of two stress events, International Journal of Central Banking, v. 16, 6, pp. 137-184, WP 1201 (November 2018).

BotTERo M., F. MEZZANOTTI and S. LENZU, Sovereign debt exposure and the Bank Lending Channel: impact on credit supply and the real economy, Journal of International Economics, v. 126, article 103328, WP 1032 (October 2015).

BRIPI F., D. LOSCHIAVO and D. REVELLI, Services trade and credit frictions: evidence with matched bankfirm data, The World Economy, v. 43, 5, pp. 1216-1252, WP 1110 (April 2017).

BRONZINI R., G. CARAMELLINO and S. MAGRI, Venture capitalists at work: a Diff-in-Diff approach at latestages of the screening process, Journal of Business Venturing, v. 35, 3, WP 1131 (September 2017).

BRONZINI R., S. MOCETTI and M. MONGARDINI, The economic effects of big events: evidence from the Great Jubilee 2000 in Rome, Journal of Regional Science, v. 60, 4, pp. 801-822, WP 1208 (February 2019).

COIBION O., Y. GORODNICHENKO and T. ROPELE, Inflation expectations and firms' decisions: new causal evidence, Quarterly Journal of Economics, v. 135, 1, pp. 165-219, WP 1219 (April 2019).

CORSELlO F. and V. NiSPI LANDI, Labor market and financial shocks: a time-varying analysis, Journal of Money, Credit and Banking, v. 52, 4, pp. 777-801, WP 1179 (June 2018).

COVA P. and F. NATOLI, The risk-taking channel of international financial flows, Journal of International Money and Finance, v. 102, WP 1152 (December 2017).

D'Alessio G., Measurement errors in survey data and the estimation of poverty and inequality indices, Statistica Applicata - Italian Journal of Applied Statistics, v. 32, 3, WP 1116 (June 2017).

DEL PRETE S. and S. FEDERICO, Do links between banks matter for bilateral trade? Evidence from financial crises, Review of World Economic, v. 156, 4, pp. 859 - 885, WP 1217 (April 2019).

D'Ignazio A. and C. MEnOn, The causal effect of credit Guarantees for SMEs: evidence from Italy, The Scandinavian Journal of Economics, v. 122, 1, pp. 191-218, WP 900 (February 2013).

ERCOLANI V. and F. NATOLI, Forecasting US recessions: the role of economic uncertainty, Economics Letters, v. 193, WP 1299 (October 2020).

MAKINEN T., L. SARNO and G. ZINNA, Risky bank guarantees, Journal of Financial Economics, v. 136, 2, pp. 490522, WP 1232 (July 2019).

MOdEnA F., E. RETTORE and G. M. TANZI, The effect of grants on university dropout rates: evidence from the Italian case, Journal of Human Capital, v. 14, 3, pp. 343-370, WP 1193 (September 2018).

NisPi LANDi V., Capital controls spillovers, Journal of International Money and Finance, v. 109, WP 1184 (July 2018).

PERICOLI M., On risk factors of the stock-bond correlation, International Finance, v. 23, 3, pp. 392-416, WP 1198 (November 2018).

RAINONE E., The network nature of OTC interest rates, Journal of Financial Markets, v.47, article 100525, WP 1022 (July 2015). 
RAINONE E. and F. VACIRCA, Estimating the money market microstructure with negative and zero interest rates, Quantitative Finance, v. 20, 2, pp. 207-234, WP 1059 (March 2016).

RIZZICA L., Raising aspirations and higher education. Evidence from the UK's widening participation policy, Journal of Labor Economics, v. 38, 1, pp. 183-214, WP 1188 (September 2018).

SANTIONI, R., F. SCHIANTARELLI and P. STRAHAN, Internal capital markets in times of crisis: the benefit of group affiliation, Review of Finance, v. 24, 4, pp. 773-811, WP 1146 (October 2017).

SCHIANTARELli F., M. STACCHINI and P. STRAHAN, Bank Quality, judicial efficiency and loan repayment delays in Italy, Journal of Finance, v. 75, 4, pp. 2139-2178, WP 1072 (July 2016).

2021

AlBanese G., E. CIANI and G. DE Blasio, Anything new in town? The local effects of urban regeneration policies in Italy, Regional Science and Urban Economics, v. 86, WP 1214 (April 2019).

Fidora M., C. GIORDANO and M. SCHMITZ, Real exchange rate misalignments in the Euro Area, Open Economies Review, v. 32, 1, pp. 71-107, WP 1162 (January 2018).

Li F., A. Mercatanti, T. MAKInEN and A. Silvestrini, A regression discontinuity design for ordinal running variables: evaluating central bank purchases of corporate bonds, The Annals of Applied Statistics, v. 15, 1, pp. 304-322, WP 1213 (March 2019).

LosCHIAvo D., Household debt and income inequality: evidence from Italian survey data, Review of Income and Wealth. v. 67, 1, pp. 61-103, WP 1095 (January 2017).

NisPi LANDi V. and A. SchiAVONE, The effectiveness of capital controls, Open Economies Review, v. 32, 1, pp. 183-211, WP 1200 (November 2018).

Pereda Fernandez S., Copula-based random effects models for clustered data, Journal of Business \& Economic Statistics, v. 39, 2, pp. 575-588, WP 1092 (January 2017).

\section{FORTHCOMING}

Accetturo A., A. Lamorgese, S. Mocetti and D. Pellegrino, Housing Price elasticity and growth: evidence from Italian cities, Journal of Economic Geography, WP 1267 (March 2020).

AlBANeSE G., G. DE BlASIO and A. LOCATELLI, Does EU regional policy promote local TFP growth? Evidence from the Italian Mezzogiorno, Papers in Regional Science, WP 1253 (December 2019).

ANZUINI A. and L. Rossi, Fiscal policy in the US: a new measure of uncertainty and its effects on the American economy, Empirical Economics, WP 1197 (November 2018).

APRIGLIANO V. and D. LIBERATI, Using credit variables to date business cycle and to estimate the probabilities of recession in real time, The Manchester School, WP 1229 (July 2019).

Baltrunaite A., C. Giorgiantonio, S. Mocetti and T. Orlando, Discretion and supplier selection in public procurement, Journal of Law, Economics, and Organization, WP 1178 (June 2018)

COVA P., P. PAgANO, A. NOTARPIETRO and M. PISANI, Secular stagnation, R\&D, public investment and monetary policy: a global-model perspective, Macroeconomic Dynamics, WP 1156 (December 2017).

DE PHILIPPIS M., Multitask agents and incentives: the case of teaching and research for university professors, Economic Journal, WP 1042 (December 2015).

Del Prete S. and M. L. SteFAni, Women as "Gold Dust": gender diversity in top boards and the performance of Italian banks, Economic Notes, Monte dei Paschi di Siena, WP 1014 (June 2015).

HERTWECK M., V. LEWIS and S. VILLA, Going the extra mile: effort by workers and job-seekers, Journal of Money, Credit and Banking, WP 1277 (June 2020).

Metelli L. and F. NATOLI, The international transmission of US tax shocks: a proxy-SVAR approach, IMF Economic Review, WP 1223 (June 2019).

MocetTi S., G. RomA and E. RuBOLINO, Knocking on parents' doors: regulation and intergenerational mobility, Journal of Human Resources, WP 1182 (July 2018).

PERICOLI M. and M. TABOGA, Nearly exact Bayesian estimation of non-linear no-arbitrage term-structure models, Journal of Financial Econometrics, WP 1189 (September 2018). 